\title{
WCZESNOCHRZEŚCIJAŃSKA SYMBOLIKA O CHARAKTERZE PONEROLOGICZNYM Wybrane przykłady
}

Symbole mają znaczenie bardzo szerokie i często uniwersalne. Należy jednak wziąć pod uwagę fakt, że symbolika starochrześcijańska wywodzi się w pierwszym rzędzie z Pisma Świętego, chociaż nie brak motywów odnoszących się do ówczesnej kultury i życia codziennego. Głównym zadaniem symboli była prosta i zrozumiała synteza głównych zasad nauki chrześcijańskiej, ukonkretnienie prawdy i objawienie Bożej ,"pedagogii”". W pierwszych wiekach istnienia Kościoła symbolika rozwijała się bardzo dynamicznie. Ten fakt był spowodowany w dużej mierze sytuacją chrześcijaństwa jako religii zakazanej i prześladowanej. Z kolei „prawo tajemnicy”" zakazywało wtajemniczania nieochrzczonych w niektóre prawdy chrześcijańskie. Znaki symboliczne były więc jasne i zrozumiałe dla chrześcijan, a trudne czy wręcz niemożliwe do zinterpretowania przez tych, „którzy są na zewnątrz” (1Kor 5, 13). Pisarze wczesnej epoki chrześcijańskiej zakładali, że ich współwyznawcy dokonując nieodzownych skojarzeń, w sposób właściwy wytłumaczą stosowane przez nich symbole i porównania. Niejednokrotnie jednak symbole miały znaczenie ambiwalentne. Obok negatywnego wydźwięku pojawiały się także aspekty pozytywne, a sam symbol w zasadzie odwołujący do dobra, mógł przyjąć konotacje negatywne. Za każdym razem ważny jest kontekst i sposób prowadzenia wywodu przez autora opisu. W literaturze starochrześcijańskiej częstym zjawiskiem jest typologia ponerologiczna, która ułatwia klasyfikację. Trudno jednak w ograniczonym objętościowo artykule poruszyć w sposób wyczerpujący zagadnienie symboliki zła, grzechu i kary. Z metodologicznego punktu widzenia najkorzystniejsze wydaje się przedstawienie niewielkiej antologii tekstów patrystycznych dotyczących symboliki ponerologicznej.

* Dr hab. Mieczysław Celestyn Paczkowski OFM, prof. UMK - kierownik Zakładu Patrologii i Antyku Chrześcijańskiego na Wydziale Teologicznym Uniwersytetu Mikołaja Kopernika w Toruniu; e-mail: celestyn@umk.pl.

${ }^{1}$ Greckie określenie znaczy tyle co „zestawienie” dwu części i „złączenie” przełamanego przedmiotu, por. Lampe, s. 1282, s.v. $\sigma \hat{\mu} \mu \beta \circ \lambda$ ov.

${ }^{2} \mathrm{O}$ disciplina arcani mówiono $\mathrm{w}$ związku z rytami sakramentalnymi. $\mathrm{Z}$ czasem zasada ta miała nieco luźniejszy charakter, więc szerokie rzesze ludu mogły słuchać jak było omawiane znaczenie rytów inicjacji, por. V. Recchi, Arcano (disciplina dell'), DPAC I 316. 
1. Fetor grzechu. Zmysł powonienia był przez filozofów lekceważony, a także przypisywano mu cechy instynktu zwierzęcego i kojarzono z efemerycznością ${ }^{3}$. Wydaje się truizmem przypominanie, że w symbolice chrześcijańskiej świętość pachnie ${ }^{4}$, a fetor wydają demony i grzechy. Przyjemna woń to jedno z powszechnych i zmysłowo uchwytnych znamion ingerencji świata nadprzyrodzonego w świat ziemski, a wonności kojarzono nierozerwalnie $\mathrm{z}$ bóstwem ${ }^{5}$. Natomiast demony i potwory wydawały drażniącą woń i nieznośny fetor. W mentalności semickiej wonności symbolizowały sprawiedliwość, która dokonuje się dzięki zachowaniu Prawa. Z kolei niewierność Prawu Bożemu także miała swoją woń, tym razem nieprzyjemną:

„Zapach sprawiedliwości wynikającej z Prawa poszedł w niepamięć na Syjonie i w jego okolicach - oto woń bezbożności jest tam”.

Fizyczność, z jej wynaturzeniami i słabościami stanowiła kompleksowy i wygodny model dla sposobu przedstawiania zła ${ }^{7}$. Były to także skuteczne argumenty w polemice antygnostyckiej. Ukazuje to komentarz do Księgi Ezechiela Orygenesa:

${ }^{3}$ Por. Origenes, De principiis I 1, 7, ed. H. Crouzel - M. Simonetti, SCh 252, Paris 1978, $104-$ 107, tłum. S. Kalinkowski: Orygenes, O zasadach, ŹMT 1, Kraków 1996, 64: „Każdemu cielesnemu zmysłowi odpowiada jakaś charakterystyczna dla niego substancja zmysłowa, do której on właśnie się zwraca. Tak więc wzrokowi podlegają barwy, kształty i wymiary, słuchowi głosy i dźwięki, węchowi przyjemne i nieprzyjemne zapachy [...] [a] wszystkim wiadomo, że zmysł umysłu jest o wiele doskonalszy od wymienionych zmysłów"; zob. także Philo Alexandrinus, De opificio mundi 62.

${ }^{4} \mathrm{~W}$ takim właśnie znaczeniu postrzegano przyjemne zapachy wyczuwalne $\mathrm{w}$ otoczeniu świętych osób, szczególnie w chwili śmierci (odor sanctitatis). Bardzo sugestywny pod tym względem jest opis śmierci żyjącego na pustyni mnicha starca Sisoesa, którego cela w chwili jego śmierci napełniła się piękną wonią (por. Apophtegmata Patrum 817; J 12, 3).

${ }^{5}$ Takich porównań używa Grzegorz z Nyssy (In Canticum canticorum hom. 1, ed. H. Langerbeck, GNO VI, 36-37, Leiden 1960, tłum. M. Przyszychowska: Grzegorz z Nyssy, Homilie do Pieśni nad pieśniami, ŹMT 43, Kraków 2007, 34) poruszając kwestię poznania Boga: „Gdy opróżni się naczynie z perfum, nie można rozpoznać aromatu, jakim naprawdę jest on z natury, ale z niewyraźnego zapaszku pozostałego w naczyniu domyślamy się woni wylanych perfum [...]. Natura woni Bóstwa przekracza wszelką normę i określenie”. Poświadcza to również Cyryl Aleksandryjski (De sancta et consubstantiali Trinitate 3, PG 75, 856C, thum. własne), mówiąc o boskiej naturze Zbawiciela: „Paweł pisze do wiernych: «Bogu niech będą dzięki za to, że pozwala nam zawsze zwyciężać w Chrystusie i roznosić po wszystkich miejscach woń Jego poznania. Jesteśmy bowiem miłą Bogu wonnością Chrystusa» (2Kor 2, 14-15). W Chrystusie wdychamy woń Boga Ojca [...]. [Wszystko, co istnieje] wydaje sobie właściwy zapach. Jakże więc Chrystus może być dla nas wonią poznania Boga Ojca, jeśli nie wierzymy w jego bóstwo? [...] Dzięki Niemu i w Nim poczuliśmy woń poznania Ojca i nią zostaliśmy ubogaceni”.

${ }^{6}$ Apocalypsis Baruch syriaca 67, 6, ed. P. Bogaert, SCh 144, Paris 1969, 512, thum. J. Woźniak: Apokalipsa Barucha syryjska, w: Apokryfy Starego Testamentu, red. R. Rubinkiewicz,Warszawa 1999, 433.

${ }^{7}$ Jednocześnie przedstawiano sposób Bożego działania. Por. W.J.B. Boyd, Origen and Pharaoh's Hardened Heart: A Study of Justification and Election in St. Paul and Origen, StPatr 7 (1966) 434-442. 
„[Bóg] jak Ojciec zna wszystkie nasze rany, zna przyczynę powstania wrzodu, wie, skąd się wywodzi gangrena nieszczęsnej duszy i jaki ból z jakiego pochodzi grzechu"; zna postaci, rodzaje i liczbę grzechów"9.

Chrystus, sam wolny od jakiejkolwiek słabości, zdolny jest zaradzić każdej człowieczej niedoli. Jednocześnie sam nie ulega zarażeniu chorobą ${ }^{10}$.

Tertulian piszący do męczenników wskazuje, że:

„o wiele wstrętniejszy [niż w więzieniu] zaduch nieczystości wydobywa się ze świata, z ludzkich namiętności”"11.

Jest to stały element identyfikacji grzechu z nieprzyjemnym zapachem. Dla Orygenesa bliskość Boga to gwarancja świętości. Człowiek zachowuje „woń boskości” jak naczynia, w których przechowywano cenne wonności ${ }^{12}$ :

„Samo naczynie zawierające pachnidło w żaden sposób nie może brzydko pachnieć, ci zaś, którzy uczestniczą w jego woni, mogą przybrać przykry zapach, jeżeli przypadkiem oddalą się nieco od niego. Podobnie Chrystus, jako naczynie [...] nie mógł przybrać złego zapachu"'13.

Wierność Chrystusowi oznacza woń cnót, o czym pisze Aleksandryjczyk w innym miejscu:

„«Jesteśmy miłą Bogu wonnością Chrystusową na każdym miejscu» (2Kor $2,15)$. My jednak, gdy tego słuchamy, cuchniemy jeszcze grzechami i występkami, o których pokutnik tak mówi u proroka: «Cuchnęły i ropiały moje rany na skutek szaleństwa mojego» (Ps 38[37], 6). Grzech ma zgnily zapach, cnota $^{14}$ zaś wonieje pachnidłami" ${ }^{15}$.

${ }^{8}$ Według Wulgaty grzech to „gangrena”, wymagająca amputacji: „Amputa opprobrium meum” (Ps 118, 39).

${ }^{9}$ Origenes, In Ezechielem hom. 5, 1, ed. M. Borret, SCh 352, Paris 1989, 192-193, thum. S. Kalinkowski: Orygenes, Homilie o Księgach Izajasza i Ezechiela, ŹMT 16, Kraków 2000, 127.

${ }^{10}$ Orygenes (Contra Celsum IV 15, ed. M. Borret, SCh 136, Paris 1968, 220-221, thum. S. Kalinkowski: Orygenes, Przeciw Celsusowi, PSP 17/1, Warszawa 1977, 290) wskazuje na to w jednym z fragmentów Contra Celsum: „Czy można powiedzieć, że lekarz, który ogląda okropności i dotyka rzeczy wstrętnych po to, by leczyć chorych, przechodzi od dobra ku złu, od piękna ku szpetocie, od szczęścia ku nieszczęściu [...]? Ten, który leczy rany naszych dusz słowem Bożym, które jest w Nim, nie może popaść w jakiekolwiek zło". Jest tam aluzja do De flatu 1 Hipokratesa. Odnośnik na podstawie Il Cristo, I: I testi teologici e spirituali dal I al IV secolo, ed. A. Orbe - M. Simonetti, Milano 1985, 471.

${ }^{11}$ Tertullianus, Ad martyras 2, 2, ed. E. Dekkers, CCL 1, Turnhout 1954, 4, thum. własne.

${ }^{12}$ Według Jana Damasceńskiego (De imaginibus 3, 34) widzialne ślady obecności Bożej to jakby naczynia zawierające moc Bożą.

${ }^{13}$ Origenes, De principiis II 6, 6, SCh 252, 286-287, ŹMT 1, 180.

${ }^{14}$ Orygenes (Contra Celsum VI 77) mówi o „osiąganiu cnoty” i „,ugruntowaniu” w niej.

${ }^{15}$ Origenes, In Canticum canticorum hom. 1, 2, ed. O. Rousseau, SCh 37, Paris 1953, 64, thum. S. Kalinkowski, Orygenes, Homilie o Pieśni nad Pieśniami, w: Św. Metody z Olimpu, Uczta; Orygenes, Homilie o Pieśni nad Pieśniami. Zachęta do męczeństwa, PSP 24, Warszawa 1980, 112-113. 
Orygenes jest przekonany, że „każda cnota ma swą własną miłą woń” ${ }^{16}$. Ps 38 zostaje użyty w kontekście „,woni śmierci” jako skutku grzechu. Zdaniem Adamancjusza na to, że śmierć jest dostrzegalna

„wskazują słowa [Chrystusa]: «Jeśli kto zachowa naukę moją, nie ujrzy śmierci na wieki» $(\mathrm{J} 8,52)[\ldots]$. Pomyśl, czy nie ma woni śmierci w ranach wywodzących się z grzechu w tych, o których powiedziano: «Cuchnęły i ropiały rany moje» (Ps 38[37], 6); może woń śmierci była w Łazarzu przed jego zmartwychwstaniem ${ }^{17}[\ldots]$. Ludzie żyjący w Chrystusie [...] nigdy nie są odpychającym zapachem"18.

Od IV wieku problem nieprzyjemnych zapachów stawał się bardziej praktyczny niż teoretyczny. Nierzadki był wówczas widok zaniedbanych, brudnych i cuchnących ascetów z pustyni ${ }^{19}$. To być może dziwiło mieszkańców miast i wsi, ale ten fakt budził również wielką ciekawość i podziw dla ich niezwykłych umartwień. Był to więc pretekst do pouczeń, że to nie woń ciała jest wyznacznikiem cnoty lub niegodziwości. Dzięki temu, że mnisi przede wszystkim naśladowali Chrystusa ${ }^{20}$ ich życie rozsiewało ,słodycz dobra”:

„Mnich odziany w dobre czyny jest jak kółko nałożone na nozdrza smoka (por. Hi 40, 26) ${ }^{21}$; czysta bowiem dusza mnicha, wydając słodką woń duchową, pieczętuje nozdrza węża, aby w nim nie czuł smrodu pożądań"22.

Podobnymi analogiami posługiwał się św. Hieronim, dla którego zło moralne należało utożsamiać z nieznośnym fetorem:

„Grzechy nasze wydają zły zapach, są zgnilizną. Jeśli jednak będziemy za nie czynili pokutę, jeśli je będziemy opłakiwali, nasze rozkładające się występki staną się wonnym olejkiem dla Pana"23

Jego śladem idzie św. Augustyn:

„Kto dalej grzeszy jest jakby pogrzebany i słusznie jest o nim powiedziane,

Na temat „woni nieśmiertelności” zob. P. Meloni, Il profumo dell'immortalità. L'interpretazione patristica di Cantico 1, 3, Roma 1975.

${ }^{16}$ Origenes, Scholia in Canticum canticorum, ed. W.A. Behrens, GCS 33, Leipzig 1925, 221, tłum. własne.

${ }^{17}$ Orygenes cytuje 2Kor 2, 15-16.

${ }^{18}$ Origenes, Commentarii in Joannem XX 44, ed. C. Blanc, SCh 290, Paris 1982, 256-257, thum. S. Kalinkowski: Orygenes, Komentarz do Ewangelii wedlug św. Jana, ŹMT 27, Kraków 2003, 464.

${ }^{19} \mathrm{~Np}$. Teodoret z Cyru (Theodoretus Cyrensis, Historia religiosa 6, 2, PG 82, 1358D, thum. K. Augustyniak: Teodoret z Cyru, Dzieje miłości Bożej. Historia mnichów syryjskich, ŹM 7, Kraków 1994, 138) opisuje odstraszający wygląd Szymona Starszego i przedstawia go jako „człowieka brudnego, zaniedbanego z kawałkiem koziej skóry na ramionach. Jego długie włosy sięgały do stóp”.

${ }^{20}$ Tak było np. w przypadku Antoniego Egipskiego (por. Athanasius, Vita Antonii 2).

${ }^{21} \mathrm{~W}$ niektórych thumaczeniach zamiast tego mitycznego stworzenia występuje krokodyl.

${ }^{22}$ Hyperechios, Adhortationes ad monachos 156, PG 79, 1489A, thum. własne.

${ }^{23}$ Hieronymus, Commentarius in Marcum 1, PL 30, 594 A, thum. własne. 
iż już cuchnie ${ }^{24}$ w tym sensie, że zły rozgłos o popełnionym grzechu dociera wszędzie jak nieznośny fetor"25.

Grzegorz Wielki opowiada o widzeniu domów:

„ogarniętych cuchnącym oparem” i „cuchnącej rzece, ponieważ tutaj codziennie spływa do przepaści zgnilizna grzechów cielesnych"26.

Staje się zrozumiałe, że:

„cuchnący opar dosięga tych, którzy tutaj rozkoszują się smrodem ciała. Dlatego i błogosławiony Hiob, widząc w tym smrodzie rozkoszowanie się ciałem, tak wyraził się o człowieku wyuzdanym i układnym: «Jego słodycz pełna robactwa» (Hi 24, 20)"'27.

Oprócz reminiscencji biblijnych św. Grzegorz maluje obraz realnego miasta pogrążonego w śmieciach i pozbawionego kanalizacji. Wszelkie nieczystości spływały ze wzgórza do pobliskiej rzeki. Warto przy tej okazji podkreślić, że monastyry często korzystały z rzymskich zdobyczy techniki, a systemy kanalizacyjne, melioracyjne czy wodociągowe były wzorowane na tych z czasów świetności imperium ${ }^{28}$. Jest jednak faktem, że następowało przewartościowanie rzeczywistości doczesnej. Dla mnichów czystość ducha była ważniejsza niż higiena ciała. Nie unicestwiało to jednak znaczenia symbolicznego pewnych zjawisk.

2. Ciemność i mrok. Symbolika ciemności i mroku obejmuje przede wszystkim sferę negatywną doświadczeń ludzkich: niewiedza, zło, niewiara, niebezpieczeństwo, groźne i tajemnicze siły czy śmierć. W ikonografii posługiwano się czernią, by przedstawić symbolicznie te właśnie elementy. Jak wiadomo czerń jest całkowitą nieobecnością światła, niejako zaprzeczeniem jego bogactwa i innych kolorów ${ }^{29}$. Sama w sobie jest mroczna, jest kolorem

${ }^{24}$ Nawiązanie do tekstu J 11 o wskrzeszeniu Łazarza.

${ }^{25}$ Augustinus, In Joannis Evangelium tractatus 49, 3, PL 35, 1748, tłum. W. Szołdrski W. Kania, w: Św. Augustyn, Homilie na Ewangelie i pierwszy list św. Jana, PSP 15/2, Warszawa $1977,32$.

${ }^{26}$ Gregorius Magnus, Dialogi de vita et miraculis patrum italicorum IV 38, 3, PL 77, 89D, thum. E. Czerny - A. Świderkówna i inni: Grzegorz Wielki, Dialogi, ŹM 23, Kraków 2000, 336-337.

${ }^{27}$ Tamże IV 38, 5, PL 77, 392A, ŹM 23, 337. Jako biblijny przykład podana jest kara, jaka dotknęła Sodomitów, „którzy zginęli od ognia i smrodu” (tamże IV 39, PL 77, 393D, ŹM 23, 337).

${ }^{28}$ Mnisi to ,porzymscy pionierzy zaopatrzenia w wodę i drenażu”. Por. L. Wright, Clean and Decent. The Fascinating History of the Bathroom and the Water Closet, and of Sundry Habits, Fashions and Accessories of the Toilet Principally in Great Britain, France and America, London 1971, 24.

${ }^{29}$ Por. Origenes, In Numeros hom. IX 1, 5, ed. A. Behrens - L. Doutreleau, SCh 415, Paris 1996, 228, tłum. S. Kalinkowski: Orygenes, Homilie o Księdze Liczb, w: Orygenes, Homilie o Ksieggach Liczb, Jozuego i Sędziów, PSP 34/1, Warszawa 1986, 80: „Któż by wiedział, że światłość jest dobra, gdyby nie znał nocnych ciemności?". 
nocy, w tym także sfery ciemności i śmierci ${ }^{30}$. W starożytnej grece ciemność i mrok mają takie samo znaczenie jak określenia ,czarny” i ,zły, niebezpieczny i straszny"31. Hieronim, bazujący na komentarzu Orygenesa, wyjaśnia hiperbolę Psalmisty:

„Kruk jest czarny i nie ma na nim nawet jednego białego piórka [...]. Jeśli więc za dnia jest czarny, to tym bardziej w nocy. Zastanawiając się nad sobą stałem się więc taki z powodu moich grzechów"32.

Ciemność staje się symbolem o podwójnej wymowie ${ }^{33}$. Używa się odnośników do ciemności w celu wskazania na stan preegzystencji: czas poprzedzający dzieło stworzenia (por. $\mathrm{Rdz} 1,2$ ) i okres przebywania dziecka w łonie matki ${ }^{34}$. Ciemność stanowi również czas próby, której Bóg poddaje człowieka (por. Hi 17, 12). Mroczna rzeczywistość to także przeciwieństwo świata stworzonego $\mathrm{w}$ apokaliptycznych obrazach proroka Joela. Chociaż w powszechnym mniemaniu ten dzień był momentem wybawienia dla proroka oznaczał on powrót do pierwotnego chaosu. To „dzień ciemności i mroku, dzień obłoku i mgły" (J1 2, 2). Tradycja judeochrześcijańska nie zapominając o ciemnościach i nocy jako symbolu grzechu, który oddala od Boga i poddaje człowieka władzy księcia ciemności (por. Hi 24, 13-17; Ps 91, 6), ukazuje noc jako miejsce tajemniczego spotkania człowieka z Bogiem ${ }^{35}$.

Tertulian posługuje się paradoksalnymi wyrażeniami, mówiąc o tym, że:

„świat posiada większe ciemności [niż więzienie], bo [one] zaślepiają serca ludzkie [...]. Jesteście wprawdzie w ciemnościach, ale przecież jesteście światłością"

${ }^{30}$ Czerń kojarzyła się z królestwem zmarłych. Był to kolor bogów podziemia i ich zwierząt ofiarnych w Grecji i Egipcie. Kult żydowski wykluczał tę barwę żałoby.

${ }^{31}$ Będąc przeciwieństwem naturalnego światła jest również w znaczeniu duchowym symbolem wiecznej ciemności, grzechu i szatana. Wyrażenie „,czarna dusza” oznacza po prostu ,grzeszną duszę”. W ujęciu ludowym nazywano szatana zwykle „Czarnym”.

${ }^{32}$ Origenes, In Psalmos hom. 101, 7, ed. J.B. Pitra, w: Analecta Sacra Spicilegio Solesmensi parata, III: Patres Antenicaeni, Parisiis 1883, 192-193, tłum. S. Kalinkowski: Orygenes - Hieronim, Homilie o Księdze Psalmów, ŹMT 32, Kraków 2004, 177.

${ }^{33}$ Wnętrze groty narodzenia Chrystusa jest ciemne: Zbawiciel przyszedł bowiem oświecić tych, co żyją w ciemności. Owa ciemność groty oznacza również, iż Jezus będzie musiał przejść przez mroki śmierci, aby dać nam życie.

${ }^{34}$ Hiob w swoim żalu przeklina dzień narodzin: „Niech dzień ten zamieni się w ciemność, niech nie dba o niego Bóg w górze. Niechaj nie świeci mu światło, niechaj pochłoną go mrok i ciemności” (Hi 3, 4-5).

${ }^{35}$ W nocy Jakub walczył z aniołem (por. Rdz 32, 25-30), w obłoku Mojżesz otrzymał Prawo na Synaju (por. Wj 19, 16), obłok osłaniał Izraelitów w czasie ucieczki z Egiptu (por. Wj 13, 21), obłok osłaniał namiot spotkania, w którym Mojżesz rozmawiał z Bogiem (por. Wj 40, 34-38). Por. M. Dupuy, Nuit, DSp VIII 519-525; Noc, w: Stownik teologii biblijnej, red. X. Léon-Dufour, thum. K. Romaniuk, Poznań 1990, 558-561.

${ }^{36}$ Tertullianus, Ad martyras 2, CCL 1, 4, tłum. E. Stanula: Do męczenników, w: Tertulian, Wybór pism, PSP 5, Warszawa 1970, 32-33. 
W nawiązaniu do przypowieści ewangelicznej o zaproszonych na ucztę Orygenes pisał:

„«Wyrzućcie go na zewnątrz, w ciemności» (Mt 22, 13). Wyrzucili go w nie znające zupełnie światła ciemności zewnętrzne, aby znalazłszy się w ciemnościach zewnętrznych zapragnął światła i z płaczem wołał do Boga, który ma moc zlitować się i wybawić go stamtąd"37.

W stosunku zaś do słów Psalmu Orygenes twierdzi:

„zawsze musimy pamiętać słowa Boże, zwłaszcza zaś wówczas, gdy «ciemność mnie otacza» (por. Ps 119(118), 55), gdy otaczają mnie mury, gdy przychodzi nieczyste pożądanie i niepokoi władczą cząstkę duszy"38.

Dla Hipolita Rzymskiego czerń Oblubienicy z Pieśni nad pieśniami staje się symbolem minionych grzechów Kościoła, wywodzącego się z pogan pogrążonych wcześniej $\mathrm{w}$ niewiedzy i w nieprawości ${ }^{39}$. W pozytywnym świetle ten sam motyw rozpatruje Orygenes w jednej ze swoich licznych dygresji egzegetycznych ${ }^{40}$. Kościół, przedstawiony w osobie królowej Saby, „czarnej i pięknej niewiasty"41, przychodzi do Chrystusa, swego Oblubieńca, „z ludami całego świata"42. Tym śladem idzie Grzegorz z Nyssy, opisujący proces, w którym dusza odrzuca to, co cielesne, czyli czerń i swój ciemny wygląd ${ }^{43}$.

Orygenes nie miał wątpliwości co do istnienia mocy ciemności, stanowiących odwrotność Bożego stworzenia. W sposób dosyć zawiły Adamancjusz wyjaśnia różnorodność bytów rozumnych, cielesnych i bezcielesnych:

„Jak zaś było wiele grup podległych Bogu, tak i po przeciwnej stronie są nie tylko Władze, ale również rządcy świata tych ciemności i «pierwiastki duchowe zła na wyżynach niebieskich», może też i «Zwierzchności» (por. Ef 6,12$)^{\prime 44}$.

${ }^{37}$ Origenes, Commentarii in Matthaeum XVII 24, ed. E. Klostermann - E. Benz, GCS 40, Leipzig 1935, 651, tłum. K. Augustyniak: Orygenes, Komentarz do Ewangelii wedtug św. Mateusza, ŹMT 10, Kraków 1998, 351.

${ }^{38}$ Tenże, Commentarii in Psalmos 118, 157 (in cat.), ed. M. Harl - G. Dorival, SCh 189, Paris 1972, 438-439, tłum. własne.

${ }^{39}$ Por. Hippolytus, In Danielem 31.

${ }^{40} \mathrm{~W}$ odniesieniu do Pnp 1, 5 Aleksandryjczyk przytacza serię tekstów starotestamentowych, w których mówi się pozytywnie o osobach o ciemnej skórze. Por. M. Simonetti, Między dosłownością a alegorią. Przyczynek do historii egzegezy patrystycznej, Myśl Teologiczna 26, tłum. T. Skibiński, Kraków 2000, 82, nota 58.

${ }^{41}$ Origenes, Commentarii in Canticum canticorum II 36, ed. L. Brésard - H. Crouzel - M. Borret, SCh 375, Paris 1991, 282-283, thum. S. Kalinowski: Orygenes, Komentarz do Pieśni nad pieśniami, w: Orygenes, Komentarz do Pieśni nad pieśniami. Homilie o Pieśni nad Pieśniami, Kraków 2005, 68.

${ }^{42}$ Tamże II 28, SCh 375, 276-277, tłum. Kalinkowski, s. 64.

${ }^{43}$ Por. Gregorius Nyssenus, In Canticum canticorum hom. 1, 7.

${ }^{44}$ Tenże, Commentarii in Matthaeum XVII 2, GCS 40, 580, ŹMT 10, 323. Por. tenże, De principiis I 8, 1; tenże, In Genesim hom. 15, 5; tenże, Contra Celsum V 29. 
Zarodki zła nie są jednak dziełem Boga. Nie dotyczy to:

„ciemności, które rozciągały się nad Otchłanią, nie są niestworzone; jedno i drugie wszak zostało stworzone z niczego. Posłuchaj, co Bóg mówi u Izajasza: «Ja, Bóg, stworzyłem światło i uczyniłem ciemności» $(\mathrm{Iz} 45,7)^{45}$ [...]. Wszystkie te rzeczywistości były oczywiście stworzone, ale nie wiadomo, kiedy i jak powstały" ${ }^{\prime 4}$.

Istnieje niebezpieczeństwo, że człowiek zatraci się w mroku błędu, grzechu i śmierci ${ }^{47}$. Przed tym niebezpieczeństwem Adamancjusz ostrzega w następujących sposób:

„Jak ciemność oglądana przez długi czas osłabia wzrok patrzącego, tak samo też i śmierć oglądana przez tego, kto nie zachował nauki, uśmierca, zabija i oślepia wzrok, który na nią patrzy"48.

Ślady dualizmu w symbolice, który nie był zresztą obcy samej Biblii, spotykamy w całej literaturze patrystycznej. Dotyczy to przede wszystkim przeciwstawienia światła ciemności, królestwa Chrystusa tyranii Beliala ${ }^{49}$. Tak więc Pseudo-Barnaba mówi o „synu ciemności”50. Na bazie tradycji judaistycznych, poświadczonych przez pisma qumrańskie ${ }^{51}$, pisarze wczesnego Kościoła przedstawiali wymagania wiary jako drogę światłości, której strzegą aniołowie Boży i drogę ciemności ${ }^{52}$, po której prowadzą szatan i jego anioło$w_{i}{ }^{53}$. Podobny schemat stosuje Orygenes, gdy przypomina, iż ten, kto uwierzył, „od ciemności błędów zostaje doprowadzony do światła poznania” ${ }^{54}$. Porównuje ten proces z exodusem:

„Wyjście z Egiptu symbolizuje sytuację, gdy dusza porzuca ciemności tego świata oraz ślepotę cielesnej natury i przenosi się do innego wieku, który

\footnotetext{
${ }^{45}$ Por. tenże, Contra Celsum VI 55-56.

${ }^{46}$ Tenże, In Isaiam hom. 4, 1, ed. W.A. Behrens, GCS 33, Leipzig 1925, 258, thum. S. Kalinkowski: Orygenes, Homilie o Księdze Izajasza, ŹMT 16, Kraków 2000, 32-33.

${ }^{47} \mathrm{O}$ ciemności mówi galijski autor Eucheriusz (Formulae spiritalis intellegentiae 7).

${ }^{48}$ Origenes, Commentarii in Joannem XX 39, SCh 290, 334-335, ŹMT 27, 458.

${ }^{49}$ Por. B. Studer, Demone, NDPAC I 1363.

${ }^{50}$ Por. Epistula Barnabae 4, 9. Odnośnie do gamy znaczeniowej gr. określenia $\mu \varepsilon \lambda \alpha v o ́ \varsigma, ~ \mu \varepsilon ́ \lambda \alpha \varsigma$ (,czarny”, „ciemny”) por. Lampe, s. 840.

${ }^{51}$ Por. 1QM (= Zwój Wojny) 1, 12-15. Zob. B. Nitzan, Evil and its Symbols in the Qumran Scrolls, w: The Problem of Evil and its Symbols in Jewish and Christian Tradition (Journal for the Study of the Old Testament. Supplement Series 366), ed. H. Graf Reventlow - Y. Hoffman, London - New York 2004, 85-90; A.E. Palumbo, The Dead See Scrolls and the Personages of Earliest Christianity, New York 2004, 75.

${ }^{52}$ Wyrażenie stosowane w Epistula Barnabae 20, 1.

${ }^{53}$ Por. Epistula Barnabae 18, 1-2; Didache 1, 1.

${ }^{54}$ W starożytnym Kościele nazywano katechumenów tymi, którzy „mają być oświeceni”.
} 
oznacza albo «łono Abrahama» (por. Łk 16, 22) ${ }^{55}$, jak w przypadku Łazarza albo raj, jak w przypadku łotra (por. Łk 23, 43), który uwierzył na krzyżu"56.

$\mathrm{Na}$ przemian z ciemnością pojawia się światło ${ }^{57}$, tworząc w historii Zbawienia jakby nieustanny konflikt dobra i zła, życia ze śmiercią 58 . Dla Orygenesa jest zrozumiałe, że to światłość zwycięży:

„Boska światłość jest zdolna do rozpraszania wszelkiej istniejącej ciemności, niewiedzy i zła. Dlatego pojawiając się w takiej ciemności nie zostaje przez nią pochłonięta [...]. Na skutek pojawienia się światłości zostaje rozproszona i zniweczona. Ciemność jej nie ogarnia, bo nie może istnieć i działać, lecz jest rozpraszana i wcale jej już nie ma. Tak na przykład Paweł prześladował Chrystusa, gdy Go nie znał, a popychała go ku temu jego niewiedza, którą nazwaliśmy ciemnością. Kiedy jednak prześladowana przez nią światłość zapaliła swe promienie, wówczas ciemność została rozproszona i nie mogła już pochłonąć prześladowanej przez siebie światłości. Tak samo łotr, który później okazał skruchę na krzyżu, prześladował światłość zraniony ową ciemnością; wszelako ciemność w łotrze została rozproszona, a więc nie ogarnia [ona] światłości"59.

Pewne elementy ponerologii znajdujemy w homilii drugiej In Hexaemeron Bazylego Wielkiego. Rozważania biskupa Cezarei Kapadockiej są osnute na kanwie Rdz 1, 2: „Ciemność była nad powierzchnią bezmiaru wód”. Bazyli wytyka błędy interpretujących ten werset jako zło samo w sobie, a nie brak jasności lub zaciemnienie światła. Zło byłoby zasadą przeciwstawną Bogu, który jest światłością (por. 1J 1, 5). Kaznodzieja stawia w jednym szeregu marcjonitów, walentynian i manichejczyków, uznających dualistyczną strukturę świata. Ciemność to dla nich istotowe zło, nieprzyjaciel duszy, przyczyna śmierci i przeciwieństwo cnót ${ }^{60}$. Zło nie jest boskie ani odwieczne, nie zostało też stworzone. Nie istnieje ono samoistnie, lecz jest wyłącznie przeciwieństwem dobra i jego brakiem ${ }^{61}$. Kaznodzieja kończy swój wywód:

${ }^{55}$ Według Tertuliana (Adversus Marcionem IV 34, 10) „łono Abrahama” to pośredni stan, w którym sprawiedliwi oczekują zmartwychwstania. Z kolei dla św. Ambrożego (De obitu Valentiniani 72) to ucieczka wiecznego pokoju.

${ }^{56}$ Origenes, In Numeros hom. XXVI 4, 1, ed. W.A. Behrens - L. Doutreleau, SCh 461, Paris 2001, 246, PSP 34/1, 259.

${ }^{57}$ Jasność wzbudza przeżycia pozytywne w sferze ludzkich uczuć i myśli (por. Wj 24, 10; Ez 1, 22).

${ }^{58}$ Efrem Syryjczyk (Carmina 2, 69, CSCO 187, 195, tłum. W. Kania, w: Św. Efrem - Cyryllonas - Balaj, Wybrane pieśni i poematy syryjskie, PSP 11, Warszawa 1973, 32) wprowadza tego typu symbolikę w paralelizm Ewa - Maryja. Według niego „Ewa rozlała na świat ciemność”.

${ }^{59}$ Origenes, In Joannem fragmenta 3, ed. E. Preuschen, GCS 10, Leipzig 1903, 486, ŹMT 27, 567.

${ }^{60}$ Por. Basilius Magnus, In Hexaemeron hom. 2, 4.

${ }^{61}$ Odnośnie do problemu zła u Bazylego Wielkiego zob. tenże, Quod Deus non est autor malorum, PG 31, 329-353, tłum. J. Naumowicz: Św. Bazyli Wielki, O tym, że Bóg nie jest sprawca zła, w: Bóg i zło. Pisma Bazylego Wielkiego, Grzegorza z Nyssy i Jana Chryzostoma, red. J. Naumowicz, BOK 23, Kraków 2004, 36-56. 
„Pozostawmy interpretację alegoryczną i symboliczną [...] i przyjmijmy pojęcie ciemności w sposób nieskomplikowany [...], idąc śladem zamiaru Pisma [Świętego]"62.

Kapadocczyk przy tej okazji odrzuca funkcje stwórcze przypisywane czasami aniołom, jak również obecność ,sił zła” w akcie stworzenia ${ }^{63}$.

Negatywne konotacje powiązane z ciemnością nie były obce starożytnej liturgii chrzcielnej. Cyryl Jerozolimski wyjaśnia, dlaczego formuła wyrzeczenia się szatana jest wypowiadana $\mathrm{w}$ stronę zachodu ${ }^{64}$ :

„Tak trzeba, bo zachód jest miejscem widzialnych ciemności ${ }^{65}$, a szatan sam będąc ciemnością, w ciemności rządzi. Patrząc symbolicznie w stronę zachodu, odrzekliście się tego władcy mroków i ciemności”ø6.

Tego rodzaju symbolikę odnajduje się także m.in. u Grzegorza z Nyssy:

„Ten, kto odchodzi od Chrystusa (tak bowiem nazywa Chrystusa proroctwo) i kieruje się ku zachodowi światła, gdzie mieszkają moce ciemności, ma po swojej prawej stronie wiatr północny ${ }^{67}$, udzielający mu swego złego wsparcia i wspomagający bieg w kierunku ciemności" ${ }^{\prime 68}$.

W tradycji patrystycznej symbolika światła i ciemności dopełnia się poprzez elementy parenetyczne i mistyczne ${ }^{69}$. Analiza tych aspektów wykracza

${ }^{62}$ Basilius Magnus, In Hexaemeron hom. 2, 4, ed. S. Giet, SCh 26, Paris 1949, 152-153, thum. własne.

${ }^{63} \mathrm{~W}$ tych koncepcjach pojawiał się nie tylko dualizm metafizyczny, lecz również ślad niektórych przekonań Filona z Aleksandrii (De opificio mundi 8, 31 - 9, 35).

${ }^{64}$ Symbolika ta sięga świata przedchrześcijańskiego. Starożytni umiejscawiali bramy Hadesu na Zachodzie, tam, gdzie znikało słońce. Por. Daniélou, Pisma wybrane, tłum. S. Fedorowicz, Kraków 2011, 11.

${ }^{65} \mathrm{~W}$ przeciwieństwie do wschodu, skąd pojawia się Chrystus - „słońce sprawiedliwości” (por. Mk 3, 20; Łk 1, 78). Poświadcza to tekst Tertuliana (Apologeticum 16, 9-11, ed. E. Dekkers, CCL 1, Turnhout 1954, 116, thum. J. Sajdak, POK 20, Poznań 1947, 75-76): „Modlimy się, zwróceni ku wschodowi. Ale i z was wielu [pogan] nieraz pragnąc pomodlić się do swoich niebian, porusza wargami ku wschodowi słońca. Podobnie, jeśli dzień słońca poświęcamy radości, to czynimy to z całkiem innego powodu aniżeli cześć dla słońca”. Na temat późniejszych świadectw zob. Daniélou, Pisma wybrane, s. 12-17.

${ }^{66}$ Cyrillus Hierosolymitanus, Mystagogiae 1, 4, ed. A. Piédagnel, SCh 126bis, Paris 1988, 88, tłum. W. Kania: Cyryl Jerozolimski, Katechezy przedchrzcielne i mistagogiczne, BOK 14, Kraków 2000, 320.

${ }^{67}$ Dosł. „Akwilona”. Chodzi o rzymskie bóstwo uosabiające ostry i gwałtowny, północno-wschodni wiatr.

${ }^{68}$ Gregorius Nyssenus, In Canticum canticorum hom. 10, GNO VI, 300, ŹMT 43, 159.

${ }^{69}$ Mistyka światła i ciemności służy w tradycji patrystycznej do wyrażenia przeżycia spotkania człowieka z Bogiem. Klemens Aleksandryjski, Orygenes, a najpełniej św. Grzegorz z Nyssy w $\dot{Z} y$ ciu Mojżesza ukazywali, w jaki sposób człowiek poznając Boga, tym bardziej odczuwa ciemności oddalenia, podlegając kolejnym oczyszczeniom, by doświadczać Boga ponad wszelkimi doświadczeniami zmysłowymi. Por. T. Merton, Szukanie Boga, Kraków 1983, 40. 
jednak poza ramy niniejszego studium. Należy jednak zauważyć, że identyfikacja „upadłych aniołów” z ciemnością była powszechna w literaturze chrześcijańskiej. Częste było przedstawianie w literaturze monastycznej diabła jako ciemnoskórego Etiopczyka ${ }^{70}$. Tę cechę angelus tenebrarum zachowuje także w późniejszej ikonografii, którą wzmocniły historie monastyczne z Tebaidy i biografia św. Benedykta z Nursji. Galijski autor Eucheriusz mówi o „czerni” grzesznika i demonów ${ }^{71}$. Czasami to czarny strój znamionuje pojawiające się w ludzkiej postaci siły demoniczne ${ }^{72}$. Zdarza się, że budząca przestrach postać ukazuje miejsce kaźni grzeszników. Tak było w przypadku jednego z mnichów znad Morza Martwego, który zaprowadzony do ,,jakiegoś miejsca ciemnego, o nieprzyjemnym zapachu, gdzie płonął ogień" "73 , zobaczył w nim heretyków ${ }^{74}$. Według bizantyjskich kanonów ikonograficznych z użyciem czerni przedstawiani są na ikonach potępieńcy w scenie Sądu Ostatecznego. Ludzie ci stracili wszystko, co jest życiem, zespolili się z ciemnością ${ }^{75}$.

3. Niszczący ogień. W historii ludzkości ogień był nie tylko sprawcą postępu cywilizacyjnego, ale także narzędziem wojen i zniszczenia. Ustawodawstwo Starego Testamentu nakazywało karę ognia za szczególnego rodzaju wykroczenia o charakterze moralnym ${ }^{76}$. Ludzie posługiwali się więc ogniem przy wymierzeniu kary, ponieważ tego środka używał także Bóg ${ }^{77}$. Nic więc dziwnego, że w ogólnym przekonaniu ogień łączono z mrocznymi siłami zła i grzechu. Nie bez powodu to jeden z głównych symboli wiecznej męki w piekle (por. Mt 5, 22) ${ }^{78}$.

\footnotetext{
${ }^{70}$ Por. Eudocia Augusta, Carmen de Cypriano 1, 140.

${ }^{71}$ Por. Eucherius, Formulae spiritalis intellegentiae 4. Porównanie dotyczy czarnego upierzenia kruka.

${ }^{72}$ Por. Georgius Pisida, In sanctam resurrectionem 43.

${ }^{73}$ Joannes Moschus, Pratum spirituale 26, ed. M.J. Rouët de Journel, SCh 12, Paris 1946, 66, tłum. własne.

${ }^{74}$ Ariusza odmalowywano w najczarniejszych barwach. Podobnie było z jego kontynuatorami, por. E. Bellini, Alessandro e Ario. Un esempio di conflitto tra fede e ideologia, Milano 1974; M. Girardi, Semplicità e ortodossia nel dibattito antiariano di Basilio di Cesarea: la raffigurazione dell'eretico, VigCh 15 (1978) 51-74.

${ }^{75} \mathrm{Na}$ temat ikonografii paleochrześcijańskiej sądu ostatecznego por. L. Pani Ermini, Giudizio. II. Iconografia, NDPAC II 2302-2303.

${ }^{76}$ Do takich przestępstw zaliczano: jednoczesne małżeństwo z dwoma kobietami - matką i córką oraz nierząd kobiety z rodu kapłańskiego, która w ten sposób bezcześciła osobę swojego ojca, spełniającego służbę Bożą (por. Kpł 20, 14; 21, 9). Starożytny Kodeks Hammurabiego przewidywał tę samą karę za podobne przestępstwa.

${ }^{77}$ Tak było od czasów zniszczenia Sodomy i Gomory, gdy „Pan spuścił na [nie] deszcz siarki i ognia [...] z nieba” (Rdz 19, 24). Według Księgi Mądrości „,́́nieg i lód wytrzymywały ogień i nie topniały, by pojęli, że plony nieprzyjacielskie zniszczył ogień, płonąc wśród gradu i wśród ulewy błyskając" (Mdr 16, 22).

${ }^{78}$ Oddalenie się od Boga powoduje, że człowiek zostaje wrzucony w ogień piekielny, tak jak diabeł i jego aniołowie (por. Mt 25, 41-46).
} 
Zdaniem Orygenesa:

„ogień, który spada na grzeszników i który pali ich wnętrzności, jest niewidzialny, duchowy, karcący. Jeśli chcesz przywołać obraz tego ognia, wyobraź sobie człowieka, którego pali ogień w wysokiej gorączce. Nie zobaczysz tego ognia, ten ogień jest wewnątrz, pali jego wnętrzności. Tak samo płonie człowiek, którego trawi gorączka grzechów"79.

Taką właśnie drogę wskazywał Adamancjusz, pisząc o „ogniu duchowym", który nie kieruje ku innej miłości ${ }^{80}$ i nawraca na właściwy szlak ${ }^{81}$. Ogień symbolizuje bowiem nie tylko karę i udrękę, lecz również działanie odnawiające, oczyszczające i zbawcze ${ }^{82}$. Wymowa tego symbolu staje się najsilniejsza i najbardziej realna, gdy działa przez niego Boża wszechmoc, a nie tylko karzący gniew.

Nad ogniem stanowiącym wieczną karę zastanawiał się św. Augustyn z Hippony:

„Nawet natura ognia wiecznego jest niewątpliwie dobra, choć ma być karą przyszłą dla potępieńców [...]. Ogień raz będzie zgubny, innym razem, gdy stosownie użyty, największe wygody i pożytki przynosi [...]. Żar ognia tak im przykry, dla niektórych stworzeń jest do życia potrzebny i pożyteczny, bo się ku temu nadaje" $"$.

Obserwacja natury stanowiła dla tego myśliciela chrześcijańskiego ważną podstawę, chociaż nie umykały jego uwadze głębsze prawdy. Skłaniał ku temu także fakt, że w swoim przepowiadaniu Chrystus używał niejednokrotnie obrazowych określeń związanych z ogniem. Słowa ,gdzie robak ich nie umiera i ogień nie gaśnie” $(\mathrm{Mk} 9,48)$ należy rozumieć we właściwy sposób, przekonuje Doctor gratiae:

„Ci, którzy obie te kary, czyli ogień i robaka, chcą zaliczyć do kar ducha, a nie do kar cielesnych, powiadają, że również ludzie wyłączeni z królestwa Bożego, za późno i bez skutku żałując, gorzeć będą płomieniem boleści ducha, i dlatego, jak twierdzą, w miejsce owego płomienia boleści stosownie można wstawić ogień. Stąd owo powiedzenie Apostoła: «Któż się gorszy, żebym ja nie płonął?» (2Kor 11,29). W taki sam sposób trzeba rozumieć owego

${ }^{79}$ Origenes, Scholia in Iob 20, 25, w: ed. J.B. Pitra, w: Analecta Sacra Spicilegio Solesmensi parata, III: Patres Antenicaeni, Parisiis 1883, 368-369, tłum. własne.

${ }^{80}$ Odnośnie do tej tematyki por. H. Pietras, L'amore in Origene, w: Dizionario di spiritualità biblico-patristica. I grandi temi della S. Scrittura per la „Lectio Divina”, ed. S.A. Panimolle, III: Amore - carità - misericordia, Roma 1993, 262-263.

${ }^{81}$ Por. Origenes, In Lucam hom. 21, 2.

${ }^{82}$ Por. Ogień, w: Stownik teologii biblijnej, s. 615-620.

${ }^{83}$ Augustinus, De civitate Dei XII 4, ed. D. Gentili - A. Trapè, NBA 5/2, Roma 1988, 154-155, tłum. W. Kornatowski: Św. Augustyn, O Państwie Bożym. Przeciw poganom ksiąg XXII, II, Warszawa 1977, 54. 
robaka. Bo mówią, że jest napisane: «Jak mól odzienie, a czerw drewno, tak smutek toczy serce męża» (Prz 25, 20). Lecz ci, którzy nie wątpią, że w cierpieniach tych znajdzie się kara i duszy, i ciała, utrzymują, że ciało palić się będzie w ogniu, a duszę toczyć będzie jakby robak smutku [...]. Dlatego też [...] logicznie trzeba zrozumieć, że przy takim cierpieniu ciała również dusza będzie się męczyła w daremnym żalu. Przeto w starych Pismach czytamy: «Dla bezbożnego ciała karą jest ogień i robak» (Syr 7, 19) [...]. Czemuż tedy powiedziano: «Dla bezbożnego ciała», jeśli nie z tej przyczyny, że jedno i drugie, czyli ogień i robak będą karami ciała" ${ }^{\prime 4}$.

Groźba kary ognia powinna powstrzymać ludzi od nieprawości, uważa ten sam autor.

„«Gdzie robak ich nie umrze i ogień ich nie zgaśnie» (Iz 66, 24; Mk 9, 44). Słyszą to ludzie i lękają się tego, co prawdziwie stanowi przyszłość grzeszników i powstrzymują się od grzechu" $"$.

W literaturze monastycznej znaleźć można odnośnik do karzącego ognia we „wzorcowej medytacji” o rzeczach ostatecznych. Celem napomnienia Ewagriusza z Pontu ${ }^{86}$ jest wzbudzenie „bojaźni Bożej”87:

„Rozważ zawstydzenie, jakiego doznają grzesznicy przed obliczem Chrystusa i Boga, wobec aniołów i archaniołów, potęg i wszystkich ludzi. Zważ także na wszystkie męki, na ogień wieczny, na robaka, który nie umiera (por. Mk 9,48 ), na ciemności piekielne, a nadto na zgrzytanie zębów (por. Mt 8, 12), strach i męki" $"$.

Obraz ognia zespolił się na stałe z piekielną otchłanią i wieczną karą.

4. Wąż starodawny - smok. Natchnione teksty używają określenia „smok” i „wąż” zamiennie. Podobna wieloznaczność pojawia się w opowiadaniach mitologicznych ${ }^{89}$. W starożytnych działach przyrodniczych w taki sam sposób nazywano wielkie węże. Augustyn z Hippony, zestawiając największe i najmniejsze ze stworzeń mówi o „olbrzymich smokach” i ,najmniejszych robaczkach"90. Dla ludzi późnego antyku, smoki były trudnymi do identyfikacji

${ }^{84}$ Tamże XXI 9, 2, NBA 5/3, 184-185, thum. Kornatowski, II, s. 519.

${ }^{85}$ Tenże, Enarrationes in Ps. 127, 7, ed. V. Tarulli, NBA 28, Roma 199322, 174-175, thum. własne.

${ }^{86}$ Ten znany teoretyk życia duchowego stworzył syntezę pomiędzy duchowością Ojców Pustyni i myślą Orygenesa, starając się ując w zwarty system jego naukę, lecz pomijając niektóre istotne kwestie, por. F. Refoulé, Rêves et vie spirituelle d'après Evagre le Pontique, VS 14 (1961) Supplément nr 59, 470-516.

${ }^{87} \mathrm{O}$ bojaźni związanej ze śmiercią mówi Cyprian z Kartaginy (De mortalitate 2).

${ }^{88}$ Apophtegmata Patrum III 2, ed. J.C. Guy, SCh 387, Paris 1993, 148-151, thum. M. Kozera: Apoftegmaty Ojców Pustyni. Seria systematyczna, ŹM 9, Kraków 1995, 92.

${ }^{89}$ Jest tam np. mowa o smoku strzegącym ogrodu Hesperyd.

${ }^{90}$ Augustinus, De civitate Dei XI 27, NBA 5/2, 146-147, thum. Kornatowski, II, s. 8. Por. tenże, De Genesis ad litteram 3, 9. 
stworzeniami o nieznanym wyglądzie i potężnej sile ${ }^{91}$. Nawet największe umysły były wówczas przekonane, że smoki istniały w rzeczywistości, panując $\mathrm{w}$ głębiach oceanów i w przestworzach ${ }^{92}$. Smok był więc wcieleniem tajemniczych sił przyrody i jej niszczącej potęgi ${ }^{93}$. Wszechstronny erudyta, jakim był Izydor z Sewilli, pisze w swoich Etymologiach:

„smok jest największym z węży i najpotężniejszym ze stworzeń na ziemi [...]. Jego siła nie tkwi w kłach, ale w ogonie, który szkodzi bardziej niż jego paszcza" $"$.

Węże i fantastyczne stwory, które kształtem do nich nawiązywały ${ }^{95}$ miały wyłącznie znaczenie negatywne, ukonkretniając zło obecne na świecie. Taką ideę chrześcijaństwo przyjęło z Biblii, gdzie niejednokrotnie pojawiają się tajemnicze monstra. Septuaginta, używając określenia „drakon”, oddaje hebrajskie słowo ,thannin”. Pod tym określeniem kryje się cała plejada nieznanych autorom biblijnym zwierząt ${ }^{96}$.

Symbolika chrześcijańska odwołując się do smoka podkreśla jego identyfikację z szatanem ${ }^{97}$. Dla autorów chrześcijańskich nie ulega wątpliwości, że to on ,został wygnany z raju, oszukał Ewę i znalazł się na świecie"98. Według księgi Apokalipsy obraz strącenia smoka to zło pokonane: „Został strącony wielki smok, wąż starodawny, który się zwie diabeł i szatan, zwodzący całą

${ }^{91}$ Smoki w znanej nam postaci to jednak tylko ostatnie ogniwo legend i fantastycznych opowieści rodem ze średniowiecza, przywołujących czyny dzielnych rycerzy w walce z potworami, aby ocalić niewinnych i słabych. Te fantastyczne zwierzęta utożsamiane były również z Lewiatanem, wężem rajskim, hydrą czy bazyliszkiem, por. S. Kobielus, Bestiarium chrześcijańskie. Zwierzęta w symbolice i interpretacji. Starożytność i średniowiecze, Warszawa 2002, 294.

${ }^{92}$ Wiedzę o różnych dziwnych bestiach czerpano z dzieł Pliniusza czy z Fizjologa, napisanego prawdopodobnie w Aleksandrii w III lub IV w., por. L. Ward - W. Steeds, Demony. Wizje zła w sztuce, thum. E. Romkowska, Warszawa 2008, 91.

${ }^{93}$ Por. D. Forstner, Świat symboliki chrześcijańskiej, tłum. W. Zakrzewska - P. Pachciarek R. Turzyński, Warszawa 1990, 307-308.

${ }^{94}$ Isidorus Hispalensis, Etymologiarum lib. XII 4, 4, PL 82, 442BC: „Draco major cunctorum serpentium, sive omnium animantium super terram [...]. Vim autem non in dentibus, sed in cauda habet, et verbere potius quam rictu nocet”, tłum. własne.

${ }^{95}$ Por. Bestiariusz, tłum. R. Sasor, Kraków 2005, 55: „Żmija jest rodzajem smoka”.

96 „Smokiem” jest więc potwór morski (por. Ps 104, 26; Hi 40, 15. 25), dlatego księga Hioba precyzuje, że chodzi o „smoka głębiny” (Hi 7, 12). O Bogu mówi się: „Ty ujarzmiłeś morze swą potęgą, skruszyłeś głowy smoków na morzu" (Ps 74, 13; por. również Ps 148, 7). W przekazach biblijnych cechami smoka był obdarzony krokodyl (por. Hi 40, 25) lub wąż o ogromnych rozmiarach. Por. M. Lurker, Słownik obrazów i symboli biblijnych, tłum. K. Romaniuk, Poznań 1989, 219-220.

${ }^{97} \mathrm{Na}$ temat ogólnej wizji symboliki przypisywanej smokowi por. A. Quacquarelli, Il leone e il drago nella simbolica dell'età patristica, Bari 1975; Animali simbolici: alle origini del bestiario cristiano, ed. M.P. Ciccarese, Bologna 2002, 380.

${ }^{98}$ Origenes - Hieronymus, Tractatus sive hom. in Ps. 103, 26, ed. G. Morin, CCL 78, Turnhout 1958, 183, tłum. S. Kalinkowski: Orygenes - Hieronim, Homilie o Księdze Psalmów, ŹMT 32, Kraków 2004, 186. 
zamieszkałą ziemię" (Ap 12,9)99. Na podstawie tego tekstu kojarzono węża kusiciela $\mathrm{z}$ raju z szatanem ${ }^{100}$. Jednak, jak przypomina Ireneusz z Lyonu:

„smok, wąż starodawny, został związany i poddany człowiekowi, [ongiś] pokonanemu, by cała jego potęga została zdeptana"101.

Pisarze Kościoła byli jednak świadomi, że należy odróżnić zło samo w sobie od pełzającego gada ${ }^{102}$. W celu uwydatnienia negatywnego znaczenia symbolu smoka - „starodawnego węża” powstała nawet fantastyczna etymologia ${ }^{103}$.

Biskup Cezarei Euzebiusz pisze, że cesarz Konstantyn kazał sporządzić nad wejściem do pałacu płaskorzeźbę, na której został on przedstawiony ze znakiem krzyża,

„niżej zaś w postaci smoka spadający w przepaść ów nieprzyjaciel rodzaju ludzkiego, który za pośrednictwem bezbożnych tyranów zwalczał Kościół Boży. Bowiem zapowiedzi w księgach proroków Bożych opisywały go jako smoka i wijącego się węża"104.

Wspomniany cesarz kazał wybijać na monetach wizerunek węża, strąconego w przepaść zwycięskim sztandarem cesarskim (labarum). Jako wizerunek szatana, smok pojawił się na kartach dzieł Orygenesa, a potem echa tego przekonania brzmiały w tradycji chrześcijańskiej ${ }^{105}$. Według Hezychiusza z Jerozolimy biblijna Księga Psalmów

„[...] określa w sposób ogólny jako smoka całą moc przeciwnika. Z jednej strony ponieważ posiada on śmiertelny jad, a $z$ drugiej strony [jego postać] przypomina o dramacie, który miał miejsce w raju, gdy nieprzyjaciel przybrał postać węża i oszukał pierwszego człowieka stworzonego [przez Boga]. Ich głowy Chrystus zmiażdżył nad wodami, gdy pozwolił się ochrzcić i udzielił ludziom łaski chrztu. Głową duchowych smoków jest grzech"106.

${ }^{99} \mathrm{~W}$ walce prowadzonej w niebiosach archanioł Michał ,pochwycił smoka, węża starodawnego, którym jest diabeł i szatan, i związał go na tysiąc lat” (Ap 20, 2).

100 Por. Justinus, Dialogus cum Tryphone Judaeo 39, 6; 70, 5; 103, 5; 124, 3-4; Tertullianus, Adversus Judaeos 10, 10; tenże, Adversus Marcionem III 16, 7; tenże, De carne Christi 17, 5; Origenes, In Jeremiam hom. 20, 7.

${ }^{101}$ Irenaeus, Adversus haereses III 23, 7, ed. A. Rousseau - L. Doutreleau, SCh 211, Paris 1974, 466-467, thum. własne.

${ }^{102}$ Por. Theophilus Antiochenus, Ad Autolycum II 28, 6; Origenes, Contra Celsum IV 36; VI 13; Epiphanius, Panarion XXXVII 1, 6.

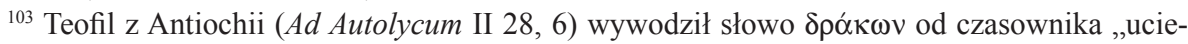
kać”. „Starodawny wąż” uciekł bowiem sprzed oblicza Bożego.

${ }^{104}$ Eusebius Caesariensis, Vita Constantini 3, 3, PG 20, 1057, thum. T. Wnętrzak: Euzebiusz z Cezarei, Życie Konstantyna, ŹMT 44, Kraków 2007, 170.

${ }^{105}$ Por. Biblia w kulturze świata. Interpretacja i symbolika, red. T. Jelonek - L. Rotter, Kraków 2006, 83.

${ }^{106}$ Hesychius Hierosolymitanus, De titulis Psalmorum 73, PG 93, 1242-1244, thum. własne. 
Wizerunek smoka był wyłącznym odnośnikiem do sfery zła również w szerszym znaczeniu. Był on więc zwierzęciem szczególnie demonicznym, kojarzonym z ciemnością i otchłanią. Przekonany był o tym Augustyn z Hippony:

„Przez smoki rozumiemy wszystkie demony, które walczą na rozkaz diabła.

Zatem jako pojedynczego smoka [...] kogo mamy uważać, jeśli nie samego diabła?"107.

Szatan to „czyhający smok”108. Jednak Doctor gratiae utożsamia smoki z demonicznymi posłańcami walczącymi pod rozkazami diabła.

Fantastyczne stwory szczególnie często spotykali mnisi na Pustyni Egipskiej. W przeciwieństwie do nich asceci syryjscy odnotowywali takie fakty niezwykle rzadko ${ }^{109}$. Można jednak zaryzykować twierdzenie, że ujarzmianie potworów stanowiło popularny topos literatury monastycznej. W opowiadaniach o ascetach syryjskich mówi się nie o wężach, lecz o smokach, których nie identyfikuje się z demonami, chociaż podobnie jak one, wzbudzają strach i giną dzięki znakowi krzyża ${ }^{110}$. Inaczej skonstruowane jest opowiadanie Grzegorza Wielkiego. Opisuje on, jak pewien młody mnich doświadczył zła w jego demonicznej postaci:

„Uległ [on] pokusie niestałości i nie chciał pozostać w klasztorze [...] [i] za żadną cenę nie zgadzał się żyć dłużej we wspólnocie, tylko wciąż usilnie prosił, by go puszczono".

Gdy wreszcie opuścił krąg monastyru:

„ujrzał na drodze smoka, który groził mu szeroko otwartą paszczą. Widząc, że zamierza go pożreć, cały drżący, zaczął wołać wielkim głosem: «Chodźcie szybko, bo smok mnie pożre!» Przybiegli bracia, nie zobaczyli jednak żadnego smoka, ale przerażonego i roztrzęsionego mnicha przyprowadzili z powrotem do klasztoru. Od razu też złożył przyrzeczenie, że nigdy klasztoru nie opuści i od tej chwili pozostał swemu przyrzeczeniu wierny. Modlitwy świętego [Benedykta] pozwoliły mu bowiem ujrzeć przed sobą tego smoka, za którym, nie widząc go, szedł poprzednio"111.

Pisarze pierwszych wieków chrześcijaństwa rozszerzali symbolikę smoka, który oznaczał wszystkich praktykujących zło. W ten sposób tworzy się krąg „wiernych starodawnego węża” - diabła. Dla Ambrożego z Mediolanu jest to parodia Kościoła Chrystusowego. Wszyscy praktykujący zło

${ }^{107}$ Augustinus, Enarrationes in Ps. 73, 16, ed. V. Tarulli, NBA 26, Roma 1990², 886-889, thum.

J. Sulowski: Św. Augustyn, Objaśnienia Psalmów, PSP 39, Warszawa 1986, 315-316.

${ }^{108}$ Por. H. i M. Schmidt, Il linguaggio delle immagini, Roma 1988, 40.

${ }^{109}$ Por. P. Canivet, Le monachisme syrien selon Théodoret de Cyr, Théologie historique 42, Paris 1977, 120.

${ }^{110}$ Por. Theodoretus Cyrensis, Historia religiosa II 6.

${ }^{111}$ Gregorius Magnus, Dialogi de vita et miraculis patrum italicorum II 25, 1-2, PL 66, 182BC, thum. E. Czerny - A. Świderkówna: Grzegorz Wielki, Dialogi, Kraków 2000, ŹM 23, 173-174. 
spożywają „ciało smoka”, którym są grzechy:

„Podobnie, jak święci są ciałem i członkami Chrystusa, tak samo ciałem i członkami smoka są grzesznicy, jeśli nie porzucą grzechu i do niego się przywiązują. $\mathrm{Z}$ tego powodu my spożywamy ciało Chrystusa, a oni ciało smoka. My wszyscy, którzy jesteśmy złączeni z Chrystusem, cieszymy się codziennym przebaczeniem i odpuszczeniem grzechów; oni natomiast, codziennie pomnażają występki i ucztują w nieustannym kręgu ohydnych win" ${ }^{112}$.

Smok był więc również symbolem ludzi bezbożnych i prześladowców Kościoła, dlatego też według św. Ambrożego metaforycznym przedstawieniem ludzi sprawiedliwych było ukazanie ich $\mathrm{z}$ ujarzmionym smokiem ${ }^{113}$. Natomiast według Cyryla Aleksandryjskiego poganie padali na twarz przed smokiem, a nieczystemu thumowi szatanów przypisywali chwałę Bożą ${ }^{114}$.

Świętość utożsamiano ze zwycięstwem nad „starodawnym wężem” - szatanem ${ }^{115}$. Cyryl Jerozolimski przypomina, że chrzest ratuje człowieka przed pożarciem przez smoka, czyli przed potępieniem ${ }^{116}$. Zwycięstwo nad złem stało się udziałem Maryi Niepokalanej. Autor utożsamiany z Efremem Syryjczykiem pisze w następujący sposób:

„Zapomniała Ewa o truciźnie wszczepionej jej przez zabójczego smoka, który ją zwiódł i wtrącił w otchłań [...]. Podstępu użył smok stary, wielką uczynił winę Ewy, nieroztropną przywodząc do upadku [...]. Ewa ściągnęła na siebie winę - Maryja była od niej wolna" ${ }^{117}$.

Rozwijając dalej ten metaforyczny obraz autor syryjski mówi:

„wąż, perfidny pisarz, spisał wielki cyrograf winy, na mocy którego kolejne pokolenia [...] zostały dotknięte śmiercią. Podpisał go i opieczętował swoją perfidią. Z powodu oszustwa starodawny smok ujrzał, że wina Ewy została pomnożona" 118 .

W Syrii dostrzegano ścisły związek, jaki zachodzi między grzechem pierworodnym i tajemnicą odkupienia:

„Z powodu Maryi niech raduje się Adam, zraniony przez węża. To Ona

${ }^{112}$ Ambrosius, Explanatio super Ps. 37, 9, ed. M. Petschenig - M. Zelzer, CSEL 64, Vindobonae $1999^{2}, 143$, thum. własne.

${ }^{113}$ Por. Kobielus, Bestiarium chrześcijańskie, s. 296-297.

${ }^{114}$ Por. Cyrillus Alexandrinus, Homilia 4, PG 77, 992-996, thum. A. Bober: Cyryl Aleksandryjski, Ku chwale Maryi Bogarodzicy, w: A. Bober, Światła Ekumeny. Antologia patrystyczna, Kraków 1966, 78-79.

${ }^{115}$ Smok - diabeł zostaje wydany na pastwę wiernych Chrystusa. Por. Ps-Athanasius (Hesychius), De titulis Ps. 73, PG 27, 953D-954D.

${ }^{116}$ Por. Cyrillus Hierosolymitanus, Procatechesis 16; tenże, Catecheses ad illuminandos 3, 11-12.

${ }^{117}$ Ephraem Syrus, Carmen 18, 1, ed. E. Beck, CSCO 187, Louvain 1959, 179-180, thum. W. Kania, OŻ 4, Kraków 1982, 36-37.

${ }^{118}$ Tamże 18, 24, CSCO 187, 182, OŻ 4, 37. 
przyniosła mu ozdrowieńcze zioło ${ }^{119}$ : przez Nią karmiony przepędził żmiję, lecząc ukąszenie węża, który go zabił"120.

Chrystus dał swoim wiernym moc pokonywania zła. Tradycja syryjska nawiązuje przy tej okazji do Łk 10, 19:

„[Stało się to], ponieważ nasz Pan oddalił błąd, panujący z powodu węża, aby nastała prawda Tego, który dał władzę nad wężami, by zostały zdeptane [...].

Ponieważ wąż ukąsił piętę Ewy, stopa Maryi go zgniotła"121.

Jako zwycięzcę smoka sztuka chrześcijańska przedstawiała archanioła Michała. Dołączyli do niego tacy święci, jak konny rycerz Jerzy (w rzeczywistości męczennik) i Małgorzata, dziewica i męczennica ${ }^{122}$. Sztuka romańska sięgała często po motyw smoka zdobiąc nim kapitele kolumn, podstawy świeczników lub upiększając inicjały. Wymowa wykorzystania tego motywu jest zawsze taka sama: przedstawiano klęskę szatana i triumf Chrystusa: poczynając od upadku aniołów i szatana, poprzez węża zwodzącego Adama i Ewę, do czasów istnienia Kościoła, gdy smok wyrusza do walki z tymi, którzy strzegą przykazań Boga ${ }^{123}$.

5. Archetyp przeciwników - Amalekici ${ }^{124}$. Identyfikacja Amaleka i Amalekitów ze złem to znacząca zbieżność pomiędzy tradycjami judaistyczną a chrześcijańską. Materiał dostarczony przez midrasze ${ }^{125}$ pozwala na rozpoznanie zakresu rozważań judaizmu na temat imienia ,Amalek”126. Nawet, gdy Amalekici przestali istnieć jako naród, w liturgii synagogalnej wymieniano ich jako synonim wrogów. Wzmianki we wczesnej literaturze chrześcijańskiej pozwalają ustalić, że wizja ta nie była obca w niektórych kręgach Kościoła.

Negatywna typologia Amaleka została rozwinięta już przez Justyna ${ }^{127}$. Wzmianka o wrogu ludu Bożego znajduje się na wstępie całego szeregu

${ }^{119}$ Autorzy syryjscy używali metafory soli, która chroniła przed jadem „starodawnego węża”, por. Aphraates, Demonstrationes 2; Ephraem Syrus, Hymni de Nativitate 8, 3. Odnośnie do tej metafory użytej przez Afrahata por. N.I. Fredrikson, La métaphore du sel et du serpent chez Aphraate, le Sage persan, RHR 219 (2002) 35-54.

${ }^{120}$ Ephraem Syrus, Hymni de Beata Maria 1, 6, ed. T.J. Lamy: Sancti Ephraem Syri Hymni et Sermones, II, Malines 1886, 521-522, thum. własne.

${ }^{121}$ Tenże, In Diatessaron 10, 13, ed. L. Leloir, SCh 121, Paris 1966, 191, tłum. własne.

122 Por. Forstner, Świat symboliki chrześcijańskiej, s. 304-308; Kobielus, Bestiarium chrześcijańskie, s. 294-298.

${ }^{123}$ Por. A.E. Bernstein, Jak powstało piekło. Śmierć i zadośćuczynienie w świecie starożytnym oraz początkach chrześcijaństwa, tłum. A. Piskozub-Piwosz, Kraków 2006, 302.

${ }^{124}$ Wiele wątków tego paragrafu zostało przejętych z mojego opracowania Amalek i Amalekici w źródłach biblijnych, judaistycznych i patrystycznych, „Quaestiones Selectae” 23 (2009) 85-113.

${ }^{125}$ Por. przede wszystkim hasła Midrash, w: Encyclopaedia Judaica, XI, Jerusalem 1972, $1507-$ 1523; F. Manns, Le Midrash - Approache et Commentaire de l'Écriture, Jerusalem 1990.

${ }^{126}$ To przede wszystkim autorzy syryjscy zachowują wiernie wątki refleksji midraszy.

${ }^{127}$ Por. Justinus, Dialogus cum Tryphone Judaeo 49. W geście rozłożonych rąk apologeta do- 
argumentów przywoływanych przeciwko Marcjonowi ${ }^{128}$. Natomiast Ireneusz z Lyonu ukazuje Amaleka na płaszczyźnie duchowej, podobnie jak zrobi to Orygenes piszący przeciwko poganinowi Celsusowi ${ }^{129}$. Dla autora Adversus haereses na pierwszy plan wysuwa się jednak kwestia chrystologiczna, bowiem modlitwa błagalna Mojżesza to zapowiedź ofiary Chrystusa na krzyżu. Poświadcza to ponadto wzmianka w Wykładzie nauki apostolskiej: to właśnie Zbawiciel otrzymał ,dziedzictwo ojców” i „uwolnił nas od Amaleka, rozkładając swoje ręce [...]. Zabiera nas i wprowadza do królestwa Ojca"130.

Typologia ponerologiczna Amalekitów znalazła swoje odbicie w rozważaniach Tertuliana. Zwraca on uwagę na postawę zewnętrzną modlącego się Mojżesza:

„Wtedy [...], gdy Jozue walczył z Amalekitami (cum Iesus adversus Amalech proeliabatur), modlił się o coś tak wielkiego, siedząc ze wzniesionymi rękami. Przecież wtedy w sprawach tak przerażających, powinien on raczej na klęczkach polecać Bogu swą modlitwę $[\ldots]^{131}$. Chyba, że tam, gdzie chwała Pańska walczyła, i mieli zamiar walczyć kiedyś przeciw diabłu, była konieczna także postawa krzyża, przez który Jezus miał odnieść zwycięstwo (dimicaturi quandoque adversus diabolum, crucis quoque erat habitus necessarius, per quam Iesus victoriam esset relaturus)"132.

Podobne elementy, jak jego „mistrz”133, akcentuje biskup Kartaginy Cyprian. W drugiej księdze Świadectw skierowanych do Kwiryniusza pisze:

„Przez [ten] znak kamienia i usilną prośbę Amalek został zwyciężony przez Jozuego [= Jezusa]. To znaczy, że diabeł został pokonany przez Chrystusa"134.

Natomiast Orygenes przekonuje, że zwycięża się nie potęgą oręża, ale

strzega potęgę krzyża, do czego nawiązuje wielokrotnie (por. tamże 91.92 i 131). Podobnie jest u Ireneusza (Demonstratio praedicationis apostolicae 46) i Tertuliana (Adversus Marcionem III 18).

${ }^{128}$ Por. Irenaeus, Demonstratio praedicationis apostolicae 33, 1.

${ }^{129}$ Por. Origenes, Contra Celsum VII 18. Celsus, podobnie jak Marcjon, starał się wykazać zasadnicze różnice pomiędzy obrazem Boga ze Starego Testamentu a Chrystusem.

${ }^{130}$ Irenaeus, Demonstratio praedicationis apostolicae 46, ed. A. Rousseau, SCh 406, Paris 1995, 150-151, thum. W. Myszor: Św. Ireneusz z Lyonu, Wykład nauki apostolskiej, ŹMT 7, Kraków 1997, 65.

${ }^{131}$ Tertulian (De oratione 15-16) potępiał praktykę siadania podczas zgromadzeń liturgicznych, gdy kończono modlitwy. Według jego opinii jest to postawa znamionująca brak szacunku wobec obecności Bożej. Afrykańczyk poleca cichą modlitwę ze wzniesionymi rękami (por. tamże 17).

${ }^{132}$ Tertullianus, Adversus Marcionem III 18, 6, ed. A. Kroymann, CCL 1, Turnhout 1954, $532-$ 533, thum. S. Ryznar: Tertulian, Przeciw Marcjonowi, PSP 58, Warszawa 1994, 127. Por. również tenże, Adversus Judaeos 10.

${ }^{133}$ Por. Hieronymus, De viris illustribus 53.

${ }^{134}$ Cyprianus, Ad Quirinum 2, 16, ed. G. Hartel, CSEL 3/1, Vindobonae 1868, 83: „Sacramento lapidis et stabilitate sessionis Amalech superatus est ab Jesu, id est diabolus a Christo victus est", tłum. własne. Zob. J. Daniélou, Sacramentum futuri. Essai sur les origines de la typologie biblique, Paris 1950, 144-147. 
siłą modlitwy. Wytrwanie w modlitwie to podjęcie walki, dzięki której triumfuje się nad wrogiem:

„W taki to sposób będziesz mógł pokonać wrogi ci lud Amalekitów, tak iż do ciebie będzie odnosić się zdanie: «Ponieważ Pan ukrytą ręką walczył z Amalekitami (Quia in manu occulta expugnabat Dominus Amalech)» (Wj $17,16)^{135}$. Podnieś i ty ręce do Boga, wypełnij polecenie Apostoła: «módlcie się nieustannie», a wówczas spełni się to, co napisano: «Teraz ten lud zliże wszystko wokół nas, jak cielę zlizuje na polu zieloną trawę» $(\mathrm{Lb} 22,4)$ "136.

Aleksandryjczyk mówi o „nieprzyjacielu” w znaczeniu duchowym, a w wojnie prowadzonej przez Izrael z wrogimi narodami dostrzega walkę duszy z ciałem. Podobnym torem biegnie kolejna myśl Orygenesa, który odwołuje się do etymologii i wyjaśnia:

„«Amalek» znaczy tyle, co «Ten, który pożera lud» lub «Ten, który odciąga lud» (,Amalec” vero interpretatur ,, ablingens populum” vel ,,declinans populum "). Ci więc, którzy wracają do świętości i zwracają się ku uświęceniu $^{137}$, zabijają i niszczą doszczętnie Amaleka, tego oczywiście, który «pożera» albo «odciąga». A któż inny odciąga lud od Boga, jeśli nie wroga potęga oraz «duchowe pierwiastki zła» (por. Ef 6, 12)"138.

Podkreślając wagę uświęcenia Aleksandryjczyk jednocześnie rozwija myśl dotyczącą rzeczy ostatecznych:

„[Wierny] patrzy na dzień sądu i z oczyszczonym sercem dostrzega zarówno kary występnych, jak i szczęście świętych: tym więc sposobem zabija wszystkich książąt Amalekitów. Ci zaś [...], którzy nie myślą o przyszłym dniu sądu, podlegają książętom Amaleka [...] [On] bowiem zlizuje ten lud, pożera go i odciąga od Boga"139.

W wyjaśnieniu Rdz 36, 12. 16 pisarz aleksandryjski zauważa, że Amalek jako potomek wielu osób musi być nieprzyjacielem Izraela, który ,jako pierwszy po wyjściu Hebrajczyków z Egiptu napadł na nich w Rafidim""140. W tekście cytowane są perykopy Wj 17, 8-16 i Pwt 25, 17-18 ${ }^{141}$. Autor homilii

${ }^{135}$ Tłumaczenie według tekstu łacińskiego homilii. Inna wersja tekstu biblijnego: „Ponieważ podniósł rękę na tron Pana".

${ }^{136}$ Origenes, In Exodum hom. 11, 4, ed. M. Borret, SCh 321, Paris 1985, 336-337, thum. S. Kalinkowski: Orygenes, Homilie o Księdze Wyjścia, ŹMT 64, Kraków 2012, 278.

${ }^{137} \mathrm{Na}$ ten trop wprowadza Orygenesa wzmianka o Kadesz, które tłumaczy jako „Uświęcenie” lub „Świętość” (tenże, In Numeros hom. XIX 1, 3, ed. W.A. Behrens - L. Doutreleau, SCh 442, Paris 1999, 348: „Cades enim interpretatur sanctificatio vel sanctum”).

${ }^{138}$ Origenes, In Numeros hom. XIX 1, 3, SCh 442, 348, PSP 34/1, 193.

${ }_{139}$ Tamże XIX 1, 3, SCh 442, 348, PSP 34/1, 193. Podobnie o Amaleku mówi Pesiqta deRab Kahana 3, 8 i Filon Aleksandryjski (De migratione Abraham 143; Allegoriae legum 3, 186-186).

${ }^{140}$ Origenes, In Numeros hom. XIX 1, 5, SCh 442, 348-350, PSP 34/1, 193.

${ }^{141}$ Orygenes (In Numeros hom. XIX 1, 6, SCh 442, 352, PSP 34/1, 194) cytuje Łk 9, 62 i kon- 
zwraca uwagę na niektóre szczegóły zauważając, że:

„Amalek zaszedł drogę Izraelowi, ale nie mógł obciąć jego głowy, obciął jedynie «ogon», to znaczy, że mógł pochwycić jedynie tych, którzy znajdowali się z tyłu i szli na samym końcu «zapominając o tym, co za nimi, a wytężając siły ku temu, co przed nimi» (por. Flp 3, 13)"142.

W rozważaniach na temat $1 \mathrm{Sm}$ 15, 1-11 w cyklu homiletycznym o Księdze Liczb Orygenes wskazuje na konieczność zachowania przez chrześcijan gorliwości i czujności:

„Nie powinniśmy oszczędzać owego niewidzialnego Amaleka (illi scilicet invisibili Amalec) $)^{143}$, który zastąpił drogę ludowi pragnącemu wyjść z Egiptu, wydobyć się z ciemności tego świata i dążyć do ziemi obiecanej. On napada na nas, a jeśli spotka nas zmęczonych, słabych, oglądających się za siebie i znajdujących się na końcu, odcina nas i zabija. Dlatego trzeba dążyć do przodu, śpieszyć do tego, co przed nami, trzeba się wspinać na szczyt góry, nieustannie podnosić w modlitwie ręce ku niebu, aby w ten sposób nareszcie Amalek został pokonany"144.

Niebezpieczeństwo grożące wierzącym ze strony zła ilustrują epizody z życia króla Dawida, który nie obejmuje władzy zanim nie zwycięży Amalekitów. Powołując się na 2Sm 1, 1 Orygenes stwierdza, że zanim Amalek został pokonany:

„dokonał wielu rzezi na narodzie izraelskim i spalił bardzo wiele ich miast. Istotnie bowiem, przed przyjściem prawdziwego Dawida, [czyli] Tego, który «według ciała pochodził z rodu Dawida» (por. Rz 1, 7), wielu rzezi wśród ludu izraelskiego dokonali duchowi Amalekici, to znaczy wrogie moce (spiritales Amalechitae, quae sunt contrariae virtutes)" $" 145$.

Dla Orygenesa jest jasne, że owi „duchowi Amalekici” zniewolili przed przyjściem Chrystusa zarówno Żydów, jak i pogan ${ }^{146}$. Zwycięstwo na nimi odnosi tylko ,prawdziwy Dawid” - Zbawca i Mesjasz ${ }^{147}$.

W analizie określenia „Amalek, pierwszy z narodów”, autor aleksandryjski twierdzi, że słowa te ,nie mogą odnosić się do ówczesnych cielesnych

kluduje: „Jeśli ktoś znajdzie się na końcu, tego odetnie Amalek”.

${ }_{142}$ Tamże XIX 1, 6, SCh 442, 350-352, PSP 34/1, 193-194.

${ }^{143}$ Por. Origenes, In Leviticum hom. 6, 6, ed. M. Borret, SCh 286, Paris 1981, 296, gdzie występują podobne motywy.

${ }^{144}$ Tenże, In Numeros hom. XIX 1, 9, SCh 442, 354, PSP 34/1, 195.

${ }^{145}$ Tamże XIX 1, 10-11, SCh 442, 356, PSP 34/1, 195.

${ }^{146} \mathrm{~W}$ ten sposób Orygenes wyjaśnia wzięcie do niewoli dwóch żon króla Dawida. Cytuje przy tej okazji Rz 3, 9.

${ }^{147}$ Ta na wskroś chrześcijańska myśl może być porównana z traktatem Sanhedrin 4, 5, a przede wszystkim z Sifre do Pwt - Pisqa 67, gdzie tradycja przypisuje rabbiemu Judzie dyskusję na temat współzależności między objęciem królestwa przez Dawida i pokonaniem Amalekitów. 
Amalekitów (in carne Amalec), gdyż oni nie byli pierwsi pod względem starożytności pochodzenia”. Chodzi tu raczej o „niewidzialnego Amaleka (ad invisibilem Amalec), który wywodzi swą nazwę stąd, że odciąga narody od Boga i Jego czcicieli czyni poganami”"148, wiodąc ludzi na manowce ${ }^{149}$. „Siedzibą Amaleka" jest jego przewrotna doktryna, która przepadnie razem z nim. W ten sposób wypełni się zapowiedź, że „zginie jego potomstwo” (Lb 24, 20), którym są błędne nauki i zabobony, prowadzące na powrót do bałwochwalstwa $^{150}$. Orygenes jednak precyzuje:

„Zginie najgorsza nauka, a nie ci, w których została posiana. Amalekici symbolizują «duchowe pierwiastki zła» (por. Ef 6, 12), natomiast ich potomstwo oznacza zabobonną naukę pogan oraz wszelką herezję"151.

U Aleksandryjczyka na czoło wysuwa się interpretacja alegoryczna. Według niej Amalek to wprawdzie wróg duchowy, lecz atakujący nie tylko z powodu grzechu, bowiem konieczność walki z nim dotyka chrześcijan prowadzących uświęcone życie. Jest to nowatorski element obcy tradycji judaistycznej. Cechą wspólną autorów chrześcijańskich jest interpretacja wydarzeń Starego Testamentu w świetle Nowego, stąd tak mocne akcentowanie zwycięstwa Chrystusa nad złem i przeciwnikami. Odczytywanie w takiej perspektywie historii biblijnej, nawet mimo braku bezpośrednich powiązań, pozwala odkryć, że „Amalek” był obecny jako rzeczywistość duchowa. Nowy Testament milczy na jego temat dlatego, że nadejście Zbawcy oznaczało pojednanie całej ludzkości - Jakuba i Ezawa. Nieprzyjacielem nie jest już człowiek, bowiem wszyscy stali się braćmi, lecz „władca tego świata” i „ojciec kłamstwa” - szatan.

6. Babilonia - obraz zamieszania. W historii ludzkości miasta były wyznacznikiem postępów kultury i cywilizacji oraz znamieniem pokoju i dobrobytu. Na terenach cywilizacji śródziemnomorskiej określenie „miasto”

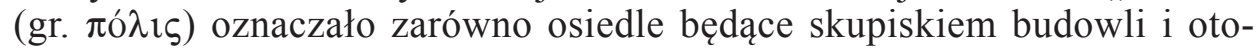
czone murem obronnym, jak i społeczność miejską czy państwo. W tym podwójnym znaczeniu kryje się już jego symbolika: miasto materialne jest symbolem elementu życia, myśli i ducha.

Izraelitów intrygowało pochodzenie miast. Autorzy biblijni przypisują powstanie architektury miejskiej i rozkwit kultury materialnej potomkom Kaina $^{152}$. Opowiadanie o wieży Babel miało wyjaśniać powstanie wielkiego

${ }^{148}$ Origenes, In Numeros hom. XIX 2, 1, SCh 442, 358, PSP 34/1, 196.

${ }^{149}$ Por. tamże.

${ }^{150}$ Por. tenże, Contra Celsum VII 18.

151 Tenże, In Numeros hom. XIX 2, 2, SCh 442, 358-360, PSP 34/1, 196.

152 Jako pierwsze pojawia się zbudowane przez Kaina miasto nazwane imieniem jego syna Henocha (por. Rdz 4, 17). 
środka miejskiego w Mezopotamii ${ }^{153}$. Natchniony pisarz biblijny w tym przedsięwzięciu dostrzega bunt przeciw Najwyższemu Bogu, który dlatego też przeszkodził w jego realizacji. Nazwa „Babel” przypominała Izraelitom o karze Bożej pomieszania języków. Babilon stał się później symbolem ziemskiej potęgi wrogiej Bogu (por. Ap 17, 1-18). Następuje swego rodzaju transformacja rzeczywistości historycznego miasta w ponadhistoryczny symbol wrogiej potęgi ${ }^{154}$. Uwydatnia to Orygenes w stwierdzeniu:

„Jeśli widzimy, że dusza ulega zamętowi pod wpływem grzechów, występków, smutku, gniewu, pożądliwości, chciwości, wiedzmy, że diabeł uprowadza ją do Babilonu"155.

Przy innej okazji nawiązuje do etymologii określenia „Babilonia”156 i za wygnanych do tego miasta uważa wszystkich, których dusze zostały ,zmącone" ${ }^{157}$ uleganiem wadom ${ }^{158}$. W pewnym okresie historii Kościoła zaczęto mówić o antagonizmie pomiędzy „miastem Bożym” a „miastem szatańskim”. Cesarstwo rzymskie jako prześladujące uczniów Chrystusa było utożsamiane z miastem nieprawości.

Dla Dydyma Ślepego wszyscy żyjący w stanie nieuporządkowania moralnego identyfikują się $\mathrm{z}$ Babilonią. Uzasadnia to $\mathrm{w}$ oparciu o etymologię Babilonii ${ }^{159}$ :

„ten, kto posiada w sobie ducha niepewnego i pełnego chaosu, jest Babilończykiem. Trzeba, aby poprawił się w swoich obyczajach i nastawieniu moralnym, jeśli chce wrócić na Syjon"160.

Dla Euzebiusza z Cezarei określenie „Babilonia” ma znaczenie przenośne ${ }^{161}$.

${ }^{153}$ Por. Rdz 11, 3-4: „Gdy [ludzie] już mieli cegłę zamiast kamieni i smołę zamiast zaprawy murarskiej, rzekli: «Chodźcie, zbudujemy sobie miasto i wieżę, której wierzchołek będzie sięgał nieba»".

${ }^{154}$ Por. Y. Hoffman, Jeremiah 50-51 and the Concept of Evil in the Hebrew Bible, w: The Problem of Evil, s. 25; K. Wengst, The Devil in the Revelation of St. John, w: The Problem of Evil, s. 70-72.

${ }^{155}$ Origenes, In Ezechielem hom. 12, 2, ed. M. Borret, SCh 352, Paris 1989, 384-385, thum. S. Kalinkowski: Orygenes, Homilie o Księdze Ezechiela, ŹMT 16, Kraków 2000, 194.

${ }^{156}$ Etymologia była doskonałym narzędziem, aby z sensu dosłownego przejść do alegorii lub doszukać się jednego z jej rodzajów. Jednak pisarze małoazjatyccy, jak chociażby Teofil z Antiochii, stosowali etymologię raczej dla potwierdzenia interpretacji dosłownej. Por. Simonetti, Między dostownościa a alegoria, s. 47, nota 109.

${ }^{157}$ Origenes, In Ieremiam hom. 2, 5, ed. P. Husson - P. Nautin, SCh 238, Paris 1977, 340-341, tłum. własne.

${ }^{158}$ Por. tenże, Selecta in Ezechielem, PG 13, 753-754, thum. własne: „Babilonia oznacza zamieszanie [...]. To stan grzechu. Jest $\mathrm{w}$ [stanie] zamiesza ten, kto nie jest wypełniony pokojem i z zgodą".

${ }^{159}$ Dydym Ślepy (Commentarius in Zachariam 1, 132, ed. L. Doutreleau, SCh 83, Paris 1962 , 262-263, tłum. własne) pisze, że „nazwa [ta] oznacza zamieszanie”.

${ }^{160}$ Tamże, thum. własne.

${ }^{161}$ Por. G. Fedalto, Il toponimo di I Petr. 5,13 nella esegesi di Eusebio di Cesarea, VetCh 20 
Według Grzegorza z Nazjanzu zaś radość chrześcijańska ${ }^{162}$ jest umotywowana tym, że:

„zostaliśmy wygnani do Babilonii przez nieuporządkowanie grzechu, teraz bezpiecznie powróciliśmy do Jerozolimy"163.

Na uwagę zasługuje przepojona alegorią interpretacja donatysty Tykoniusza $^{164}$. Ustala on antytezę ludzkości rozdzielonej w Jerozolimie i Babilonii oraz Kościoła rozdartego pomiędzy dobrymi i złymi chrześcijanami ${ }^{165}$ :

„Babilonia to miasto przeciwstawne w stosunku do Jerozolimy, [a] przedstawia cały świat zawierający się w tej jej części, którą posiada obecnie w Jerozolimie ziemskiej"166.

Egzegeta-donatysta twierdzi, że grzesznik, czyli „Babilonia”, znajduje się w obrębie Jerozolimy, czyli Kościoła. Po Tykoniuszu myśl o dwóch przeciwstawnych miastach utorowała sobie drogę w tradycji chrześcijańskiej ${ }^{167}$.

Jednak to św. Augustyn rozwinął w sposób pełny antytezę dwóch miast: Babilonu i Jerozolimy ${ }^{168}$. Wielki teolog Kościoła potraktował konflikt i przeciwstawieństwo dwóch miast w sposób symboliczny, przede wszystkim jako wyrażenie przewijających się w historii krańcowo różnych rzeczywistości. Według tej perspektywy Babilonia „to miasto, w którym króluje diabeł" ${ }^{169}$. Augustyn wystąpił przeciwko tej podwójnej wizji Kościoła. Nie tylko po sądzie ostatecznym, ale i w obecnej dobie, grzesznicy są wyłączeni z prawdziwego

(1983) 461-466.
${ }_{162}$ Nazjanzeńczyk przypomina wiernym, że poświęcenie świątyni stanowi typ i zapowiedź ich
uświęcenia.
${ }^{163}$ Gregorius Nazianzenus, Oratio 44 (In novam Dominicam), 1, PG 36, 608B, tłum. własne. Natomiast w innym miejscu Nazjanzeńczyk mówi: „Nie zapominajmy o niewoli [...], kiedy powróciliśmy bezpiecznie do Jerozolimy, ani o Egipcie, gdy opuściliśmy [go]" [Oratio 5 (Contra Julianum imperatorem), 34, ed. J. Bernardi, SCh 309, Paris 1983, 362-363, thum. własne].

164 Tykoniusz w Liber regularum (IV, PL 18, 33D-46D) przedstawił wytyczne dotyczące interpretacji biblijnej. Rozwinął tam także kategorie species i genus, które oznaczają sens dosłowny (historyczny) i alegoryczno-duchowy.

${ }^{165}$ Por. Simonetti, Między dostownościa a alegoria, s. 298 i nota 203.

${ }^{166}$ Ticonius, Liber regularum IV, PL 18, 44C (dosłownie: „tu, w dole”), thum. własne.

${ }^{167}$ Por. A. Quacquarelli, La concezione della storia nei Padri prima di S. Agostino, Roma 1955, 123-137.

${ }^{168}$ A. Lauras (A. Lauras - H. Rondet, Le thème des deux cités dans l'oeuvre de saint Augustin, w: Études augustiniennes, ed. H. Rondet i inni, Paris 1953, 97-160, spec. s. 118, nota 4) w monografii poświęconej tej antytezie konkluduje, że jest to rezultat osobistej interpretacji Augustyna. Johannes van Oort (Jerusalem and Babylon. A Study into Augustine's City of God and the Sources of his Doctrine of the Two Cities, Supplements to Vigiliae Christianae 14, Leiden 1991, 118) przychyla się do tej opinii.

${ }^{169}$ Augustinus, Enarrationes in Ps. 9, 8, ed. A. Corticelli - R. Minuti, NBA 25, Roma $1982^{2}$, 140-141, PSP 38, 106. 
Kościoła, stanowiąc tylko pozornie jego część ${ }^{170}$. Także obywatele Jeruzalem - miasta Bożego, są związani z tym światem. Nie stanowią jednak Babilonii z racji tego, że tęsknią za inną rzeczywistością. Dla biskupa Hippony fakty z historii Zbawienia stanowią okazję do spojrzenia na syntezę dziejów nakreśloną w wizerunku Jerozolimy oraz w Babilonie - mieście skazanym na klęskę jako „dom odrzucony i oddalony”"171. W analizie tego autora zawarta jest przestroga przed konsekwencjami drogi niewiary ${ }^{172}$. Podobnie, jak naród żydowski:

„musimy także i my najpierw poznać nasze zniewolenie, potem nasze wyzwolenie; musimy poznać Babilon i Jeruzalem [...]. Te dwa państwa jako miejsca historycznych wydarzeń zostały upamiętnione w Biblii. Założono je w dokładnie obranym czasie, aby wykrystalizowała się w formie symbolicznej rzeczywistość tych dwóch «państw», które zaczęły istnieć w zamierzchłej przeszłości i będą trwać aż do końca świata"173.

Pismo Święte zasugerowało nie tylko nazewnictwo i etymologię, lecz również treść teologiczną opisywanych przez Hippończyka zjawisk i wydarzeń. Biblia nadaje przede wszystkim sens symboliczno-metaforyczny obu miastom, i to właśnie tego typu znaczenie najwydatniej odcisnęło swoje piętno na antytezie Jerozolima - Babilonia. $Z$ tych pokładów wielki geniusz, jakim był Augustyn, potrafił umiejętnie korzystać. Doctor gratiae stwierdza:

„królowa [Kościół] oswobadza się z Babilonu przez odrodzenie we wszystkich narodach i odchodzi od złego króla do najlepszego Władcy, od diabła do Chrystusa" ${ }^{174}$.

Utrzymuje też, że istnieje:

,jeden Babilon i jedno Jeruzalem. Jeśli nawet określa się je mistycznymi nazwami, to chodzi [zawsze] o każde z tych miast: tamto mające za króla diabła, to Chrystusa" ${ }^{175}$.

Biskup Hippony utożsamia Babilonię ze zniewoleniem obecnej egzystencji. Podobnie jest z mocą, którą reprezentują oba miasta ${ }^{176}$. Antyteza występuje więc w całej jaskrawości, a na dodatek nasz autor upomina swoich słucha-

${ }^{170}$ Por. Ticonio, Sette regole per la Scrittura, Epifania della Parola - Testi ermeneutici A5, ed. L. i D. Leoni, Bologna 1997, 12, nota 30.

${ }^{171}$ Augustinus, De civitate Dei XVII 6, NBA 5/2, 578-579, thum. Kornatowski, II, s. 286.

${ }^{172}$ Por. tamże XVII 2.

${ }^{173}$ Augustinus, Enarrationes in Ps. 64, 1-2, NBA 26, 458-461, PSP 39, 104.

174 Tenże, De civitate Dei XVII 16, NBA 5/2, 618-619, tłum. Kornatowski, II, s. 304.

175 Tenże, Enarrationes in Ps. 61, 6, NBA 26, 348-349, PSP 39, 53.

176 Por. Augustinus, Sermo 313B, 3, ed. A. Quacquarelli - M. Recchia, NBA 33, Roma 1986, 678-679, tłum. własne: „Zęby Babilonu stanowiła [jego] moc doczesna oraz byli nimi nauczyciele zakazanych obrzędów”. Nawiązując do Pnp 4, 2 i 6, 5 Augustyn twierdzi, że zęby Jerozolimy to „ci, którzy odrzucili ciężar doczesności”. 
czy, aby nie pogrążali się w umiłowaniu Babilonii, jak również nie zapominali o Jerozolimie ${ }^{177}$. Oba miasta bowiem:

„muszą pozostać na świecie aż do końca czasów i na końcu zostaną rozdzielone. Jerozolima będzie po prawicy, Babilonia po lewicy"178.

„W rzeczywistości zagubiliśmy się i chociaż byliśmy obywatelami Jerozolimy, staliśmy się obywatelami Babilonii, synami chaosu"179.

Synonimem potępienia jest pozostanie w Babilonii i wykluczenie z Jerozolimy, gdzie:

„nie znajdą się [...] ci, których obraz Bóg zniweczy w swoim mieście i obróci w nicość. Albowiem i oni we własnym mieście, czyli w Babilonie, zniweczyli Jego obraz"180.

W rozważaniach Augustyna uderza być może uproszczone przeciwieństwo, do którego sprowadza historię Jerozolimy i Babilonu z dwoma ludami - wybranym i odrzuconym - oraz dwoma władcami - Chrystusem i diabłem:

„Podobnie, jak istnieje jedno święte miasto Jerozolima, tak jest i drugie miasto bezbożne, Babilon (una civitas sancta, Jerusalem; una civitas iniqua, Babylon). Wszyscy nieprawi należą do Babilonu, tak jak wszyscy święci do Jerozolimy. Lecz z Babilonu przechodzi się do Jerozolimy. W jaki sposób, jeśli nie poprzez działanie Tego, który usprawiedliwia grzesznika (por. Rz $4,5)$. Jerozolima to miasto wiernych, Babilon to miasto grzesznych. Jednak nadchodzi Ten, który usprawiedliwia bezbożnego"181.

Zło i chaos Babilonu rządzące ludźmi zwycięża Chrystus, który „,zszedł tu [na ziemię] jako nasz Rodak (descendit huc civis noster)" 182 .

Starożytnym pisarzom trudno doprawdy odmówić fantazji. Ich wyobrażenia nie były jednak pustymi spekulacjami lub „sztuką dla sztuki”. Opisy rzeczywistości czy repertorium ludzkich lęków, obrazy biblijne i ich typologiczno-duchowa interpretacja były środkami, aby mówić o największych

177 Tenże, Enarrationes in PS. 148, 4, NBA 28, 872-873, PSP 41, 373: „Niech was nie przyciągnie miłość do Babilonii; nie zapominajcie o Jerozolimie! Chociaż wasze ciało jest jeszcze przetrzymywane w Babilonii, niech wasze serce podąży wcześniej do Jerozolimy”.

178 Tamże 64, 2, NBA 26, 456-457, PSP 39, 105.

179 Tenże, Sermo 16A, 9, ed. M. Pellegrino - P. Bellini - F. Cruciani - V. Tarulli, NBA 29, Roma 1979, 312-313, tłum. własne. Augustyn podaje etymologię „Babilonii” w następujący sposób: „«Babylonia» enim confusio est".

${ }^{180}$ Tenże, Enarrationes in Ps. 147, 6, NBA 28, 774-775, tłum. własne.

${ }^{181}$ Tamże 86, 6, ed. T. Mariucci - V. Tarulli, NBA 27, 16-17, Roma 1993², PSP 40, 118.

${ }^{182}$ Tenże, Sermo 16A, 9, NBA 29, 312-313, tłum. własne. 
tajemnicach. Należało także opowiedzieć o tajemnicy zła, którą trzeba było ukonkretnić i nadać jej odpowiednią formę w ikonografii. Głos dawnych myślicieli i pisarzy Kościoła był twórczym uczestnictwem w dyskusji hamartiologicznej i w tworzeniu kanonu ikonograficznego późniejszych epok.

\section{THE PONEROLOGICAL SYMBOLISM IN THE ANCIENT CHURCH. SOME SELECTED EXAMPLES}

\section{(Summary)}

Ponerology is devoted to the study of evil in its different aspects. Indeed, also in the early Church it was created a kind of ponerological symbolism. This short study analyses some of these significant traditionally interpreted symbols. In the Christian symbolism holiness is full of fragrance, however the demons and sins emit a terrible odor. The symbolic value of darkness covers the negative aspects of human ignorance, evil, disbelief, danger and death. The fire represents not only illumination and light, but it has the punitive value. The serpent is first mentioned in connection with the history of the temptation and fall of the humanity. In the Christian tradition the serpent or the „dragon” represents Satan, the malicious enemy. Babylon symbolizes all that is worldly and fell away from God. St. Augustine sees the world in which he lives as a mixture of the city of confusion and the city of heaven (Jerusalem). In the ponerological symbolism appears Amalek. The Fathers equated them with passion or evil. The faithful of Christ always fights against him. In Origen this approach is much more clearly defined in his explicitly spiritualizing reading. The ponerological symbolism of the ancient Christian literature contained a moral or religious lessons or allegories.

Slowa kluczowe: patrystyka, symbolika, zło, grzech.

Key words: patristics, symbols, evil, sin. 
